\title{
Foreign ownership and market power in banking: Evidence from a world sample
}

\author{
Manthos D. Delis \\ Professor (Chair) in Financial Economics and Banking, Surrey Business School, \\ University of Surrey, Guildford, GU2 7XH, UK \\ Email: m.delis@surrey.ac.uk
}

\author{
Sotirios Kokas \\ Lecturer in Finance, Essex Business School, University of Essex \\ Wivenhoe Park, Colchester, CO4 3SQ, UK \\ Email: skokas01@ucy.ac.cy
}

\section{Steven Ongena*}

Professor of Banking, Department of Banking and Finance, University of Zurich $\mathrm{CH}-8032$, Zurich Email: steven.ongena@bf.uzh.ch

* Corresponding author. We are especially indebted to Sofronis Clerides, Robert DeYoung (editor), and two anonymous referees for many valuable comments, as well as to Stijn Claessens and Neeltje van Horen for the access to their data set on foreign ownership of banks. We are also grateful to Thorsten Beck, Paul Guest, Maria Iosifidi, Iftekhar Hasan, Vasso Ioannidou, Ioannis Kasparis, Theofanis Mamuneas, Larissa Schäfer, Thanasis Stengos, and Efthymios Tsionas and to participants of the Conference for "Banking, Finance, Money and Institutions: The Post Crisis Era", the $3^{\text {rd }}$ Conference of the Financial Engineering and Banking Society, the 11th Conference on Research on Economic Theory and Econometrics, and of seminars at the Universities of Surrey, Cyprus, and Glasgow. Delis acknowledges the support from the Centre of Money, Banking, and Institutions of the University of Surrey, and Kokas acknowledges financial support from the Department of Economics of the University of Cyprus. 


\title{
Foreign ownership and market power in banking: Evidence from a world sample
}

\begin{abstract}
The nexus between ownership and competition in the banking sector is a major concern to policymakers around the world but one that is rarely comprehensively examined. For 131 countries and 13 years we match bank ownership with over 50,000 bank-year estimates of individual bank market power. We find that ownership does not explain market power at the individual bank level. However, at the country level, foreign bank ownership has a positive and significant impact on market power mainly because foreign banks enter through mergers or acquisitions and not through greenfield investments. The observed increases in market power primarily originate from decreases in the marginal cost.
\end{abstract}

Keywords: Bank market power, competition, foreign banks, world sample JEL classification: G21; D40; F23 


\section{Introduction}

Globalization is changing the nationality of ownership of firms around the world in many sectors, and the banking sector is no exception. Claessens and Van Horen (2014) for example report that the percentage of foreign banks present in a country increased from on average $21 \%$ in 1995 to $35 \%$ in 2009 , and that in certain developing countries this increase was even substantially higher. A first-order question that at once arises is how these changes in ownership affect market power in the local banking sector. To address this question we therefore construct a new data set that includes comprehensive bank-year estimates of market power of individual banks in most countries around the world and we study the effects of foreign bank ownership on our newly-constructed estimates of individual bank market power.

Our paper addresses two crucial questions at once. First, we investigate if the ownership status, i.e., foreign or domestic, of individual banks affects their own market power. We call this the direct impact of (foreign) bank ownership. Theoretically, foreign banks could specialize in new and more specific products that are associated with higher prices and intermediation margins, or foreign banks could be the bearers of more costeffective production technologies, increasing the price-cost margins (a traditional measure of market power). These (and other similar) forces would yield higher price-cost margins for foreign-owned banks. However, foreign banks entering a new banking market might also face an informational disadvantage that would force them to price their products more competitively compared to the existing local banks, or be less cost effective for an initial period following their entry. So these forces would yield lower price-cost margins for foreign-owned banks. Therefore, the overall direct impact of foreign bank ownership on their market power is a priori ambiguous.

Second, we analyze the extent to which changes in foreign bank presence at the country (and year) level has an impact on the market power of all individual banks (which 
will comprise both foreign and domestic publicly listed banks). That is we consider whether a banking system with a higher foreign bank presence in general induces changes in individual bank market power. We call this the spillover effect. More intense foreign bank presence can trigger increased competition through the entry of new banks (greenfield entry), which leads to more competitive pricing of the banking products even for local banks (e.g., through a price war). However, the overall spillover effect of increased foreign bank presence on pricecost margins could also be positive if foreign bank presence increases rapidly and higher cost efficiency does not materialize into more competitive pricing, especially given that foreign banks could monopoly price their new products.

To empirically identify the direct impact and the spillover effect we adopt a two-step procedure. First, we estimate the individual market power of virtually all publicly listed banks in the world for which financial statements are available and comparable. For our analysis, we rely on both the Lerner index, which measures deviations of prices from marginal cost, and on the adjusted-Lerner index, which is similarly calculated but relaxes the assumption that banks function in a fully efficient manner. For the calculation of both indices we first estimate the marginal cost with a semiparametric technique that allows for greater flexibility in the production technology of banks compared to the extant parametric techniques. Thus, changes in the structure of the production technology across banks, countries and time are better accounted for. In this way we improve on the estimation of marginal cost and provide a new index of market power for the maximum amount of time and number of banking systems possible. We also examine the sensitivity of our results to the use of other commonly-used measures of market power (e.g., Lerner indices from other sources, the Boone indicator, etc.).

In the second step, we examine the relative importance of the aforementioned direct impact and spillover effect. Using the database constructed by Claessens and van Horen 
(2014) we classify all banks in our sample at each point in time as either domestic or foreignowned. Yet, despite the relevant and dynamic character of our ownership classification we fail to find - in any of the empirical exercises we do - a statistically significant (and/or economically relevant) direct effect of foreign ownership. It seems indeed there is no difference in market power between domestic and foreign-owned banks.

Next, we aggregate foreign bank presence in each country and for each year. In this case, and even when controlling for the (seemingly irrelevant) direct impact, we find that higher foreign bank presence (at the country-year level) increases the market power of the average bank in the industry (whether it is domestic or foreign-owned) in a statistically significant and robust manner. This effect is also economically relevant. For example, an increase in foreign bank presence from $17 \%$ in 1997 to $25 \%$ in 2009 (which is the increase observed for the average country in our baseline specification) results in an increase in the Lerner index by 0.07 points (for the average Lerner index in our sample of 0.22 this is equivalent to a $32 \%$ increase). These findings are not sensitive to the use of alternative specifications for the estimation of the Lerner index and to other commonly used measures of market power (for example the measurement of market power with a country-level Lerner index or a Boone indicator).

We also analyze some theoretically plausible heterogeneous effects in the identified positive relation between foreign bank presence and market power. We show that the positive effect of foreign bank presence on banks' market power is primarily due to their entry through a merger or acquisition rather than through a greenfield investment. Indeed, in our sample, two out of three foreign banks are established in the host country through a merger or acquisition and this is seemingly the main channel leading to the positive spillover effect of foreign bank presence on banks` market power. 
In addition, we find that the positive spillover effect of foreign bank ownership on the Lerner index is mainly due to the resultant lower marginal cost. In contrast, foreign bank presence does not have a statistically significant effect on the price component of the Lerner index, although this effect per se does contribute to the strong impact of foreign bank presence on the margin (gap) between price and marginal cost (and naturally on the Lerner index itself). Thus, higher foreign bank presence in a country increases the market power of banks by directly affecting the gap between output prices and marginal cost mainly through increases in the cost efficiency across banks. Importantly, this result is driven by the mode of foreign bank entry.

Our study is the first to investigate if and by how much foreign bank ownership affects individual bank market power, across certain bank and industry characteristics that may affect the relative importance of this effect. Our finding on the positive spillover effect contrasts with the only two existing empirical studies on this issue. Claessens and Laeven (2004) study a cross-sectional sample of 50 countries (with market power estimates averaged over the period 1994-2001) and Jeon, Olivero, and Wu (2011) study a country-year panel for the period 1997-2008 of Asian and Latin American countries. Both analyze the impact of foreign bank presence on bank competition at the country (and year) level. Both studies find a negative (positive) relation between foreign ownership and market power (competition).

There are a number of differentiating characteristics of our study vis-à-vis theirs that may help explain our unique findings. Most importantly based on our own estimates of individual bank market power and the foreign ownership data collected by Claessens and van Horen (2014) we can analyze the impact of a bank-level market power variable for a sample covering 131 countries over the period 1997 to 2009 (which compared to all existing studies guarantees us the broadest coverage). In contrast, existing studies focus on the relation between foreign bank entry and market power (competition) at the country or country-year 
level for a more limited number of countries. We take a number of steps (including the replication of the results of both previous studies) to show that level of the analysis and the sample coverage are the main reasons behind our finding of a positive correspondence between foreign bank presence at the country level and market power at the bank level.

The remainder of the paper is structured as follows. Section 2 provides the theoretical arguments linking foreign bank ownership with bank market power and the explicit paths that can influence this relation. Section 3 discusses the data set on the banks' market power along with the way this is estimated, and also provides definitions and information on the foreign bank ownership and the control variables. Section 4 discusses the empirical identification procedure and the estimation results. Section 5 summarizes the results and provides policy implications.

\section{Theoretical considerations and related literature}

There are two main channels through which foreign bank ownership may affect bank market power. First, foreign banks may have different levels of market power compared to domestic banks. We call this the direct impact of foreign ownership on market power. The second effect is related to the fact that foreign bank presence in the banking industry as a whole can cause changes to banks' market power, both domestic and foreign. We call this the spillover effect of foreign bank presence on bank market power. We analyze the two effects by emphasizing their sources, as these are related to the pricing of banking products or to their marginal cost. Both prices and costs may change due to the direct impact and the spillover effect, hence the price-cost margin (Lerner index), which is a common measure of market power, may be changing accordingly.

It is not a priori obvious whether the direct impact will be positive or negative. On the one hand, foreign banks have access to alternative sources of funds through their affiliates in 
their country of origin and could bring in more specialized and sophisticated banking products that are monopolistically priced. Furthermore, these banks are usually more costefficient (Bonin, Hasan, and Wachtel, 2005; Degryse, Havrylchyk, Jurzyk, and Kozak, 2012), as they have access to better technology, especially if their country of origin has a more developed banking sector compared to the one they penetrate (Claessens, Demirgüç-Kunt, and Huizinga, 2001; Micco, Panizza, and Yan, 2007). On the other hand, foreign banks entering a new market may face an informational handicap (Bofondi and Gobbi, 2006; Gormley, 2010), at least in the initial period following their entry, that could force them to price their products more competitively so that they offer better loan terms to attract customers from existing banks (Sengupta, 2007). ${ }^{1}$ Such behavior would result in a lower price-cost margin.

The direction of the spillover effect is again a priori ambiguous. Foreign bank entry can stimulate competition in domestic markets in general and put downward pressure on prices (Levine, 1996; Beck, Ioannidou, and Schafer, 2012). This effect is likely to be particularly strong in the case of greenfield entry, which adds competitors, and less so in the case of acquisitions, where a foreign bank takes over an existing domestic bank. However, there are also forces leading to a positive relation between foreign bank presence and bank market power. First, if the efficiency advantage of foreign banks forces domestic banks to become more efficient themselves, this could lead to higher margins for all banks if the cost savings are not passed on through lower prices. The same effect could arise if foreign banks are able to exploit their superior know-how and come to dominate domestic markets in new innovative financial products. If this is accompanied by a large scale and rapid penetration of foreign banking, this mechanism will naturally result to a monopolistic behavior of many

\footnotetext{
${ }^{1}$ Bofondi and Gobbi (2006) suggest that domestic banks have informational advantage with respect to their own costumers and the overall economic conditions of the local credit market.
} 
banks in the industry and the loss of competitive pricing of the monopolistic products, at least for some period of time.

Clearly, the nexus between foreign bank ownership and market power could be affected by a number of bank- and market-specific characteristics. At the bank level, a comparative advantage of the foreign banks usually comes from their access to capital from their parent companies in the origin country. Given that capital requirements are now in place in virtually all countries, this advantage of foreign banks can translate into a lower cost of capital and improved efficiency. However, if the capital market in the domestic banking system is deep and domestic banks are well-capitalized, this will weaken the implied positive relation between foreign ownership and market power. The opposite effect could prevail if there is a big difference between foreign and domestic banks in the way they finance their own lending. Usually, domestic banks have established long-term relationships with their depositors and they tend to have higher deposits to assets ratios. In contrast, foreign banks have access to potentially less expensive liquid funds from their parent companies or the international interbank market.

As discussed above, a natural differentiating factor in the impact of foreign ownership on competition is the mode of foreign bank entry. Greenfield entry increases the number of banks in the domestic banking industry, which by itself promotes competition, while penetration through an acquisition leaves the number of banks unchanged (Martinez Peria and Mody, 2004). Van Tassel and Vishwasrao (2007) and Claeys and Hainz (2014) further highlight that a foreign bank enters through a greenfield investment only if its advantage in screening new applicant firms, due to e.g. better screening technology, compensates its disadvantage of having no information about incumbent firms. If a foreign bank enters via an acquisition, it acquires a credit portfolio that contains information about the quality of incumbent firms. In addition, the acquired bank can generate information by screening 
applicants and this generates an informational advantage for foreign banks entering via acquisitions. The mode of entry, thus, determines the distribution of information between foreign and domestic banks, which affects the degree of competition in the banking industry.

The empirical evidence on the influence of the mode of entry on various aspects of banking is substantial. For example, in Mexico during the so-called tequila crisis, foreign banks entered almost entirely through the acquisition of existing domestic banks, thus preserving the oligopolistic structure of the industry (Moguillansky, Stuart, and Vergara, 2004). Also, Havrylchyk (2006) shows that Polish banks acquired by foreign banks do not show improvements in efficiency, whereas greenfield entrants tend to be more efficient than their domestic counterparts. Similarly, Peek, Rosengren, and Kasirye (1999) find that foreign banks entering the US market tend to acquire poor-performing institutions and that the performance of these institutions does not substantially improve post-acquisition. Finally, Lehner (2009) suggests that greenfield entry occurs mainly in developed countries, whereas in less developed countries entry by acquisition is more prevalent.

The relation between market power and foreign ownership can also be affected by a number of characteristics of the banking industry. Claessens, Demirgüç-Kunt, and Huizinga (2001) show that foreign banks have lower interest margins, overhead expenses, and profitability than domestic banks in developed countries, whereas the opposite is true in developing countries. Similarly, Lensink and Hermes (2004) find that foreign bank entry into less developed countries leads to higher costs and margins for the local banks, and Micco, Panizza, and Yan (2007) that foreign-owned banks in developing countries are more costefficient than private local banks. These studies suggest that the reasons for foreign entry, as well as the competitive and regulatory conditions found abroad, might differ significantly between developed and developing countries. 
Besides the two papers that are directly relevant to our work (Claessens and Laeven, 2004; Jeon, Olivero, and $\mathrm{Wu}, 2011$ ), our study is also related to two large, but rather separate, literatures: one on foreign bank participation and one on banking competition and market power. Claessens (2006) reviews and refines the full set of arguments linking the two literatures and identifies the limitations of the existing empirical evidence. Among other studies, Clarke, Cull, Martinez Peria, and Sanchez (2003), Beck, Ioannidou, and Schafer (2012) and Bruno and Hauswald (2013), find that foreign bank entry improves credit conditions for enterprises of all sizes, and Berger, Hasan, and Klapper (2004) suggest that a larger foreign bank presence leads to a greater availability of credit to SMEs (see also Giannetti and Ongena, 2009, 2012).

Detragiache, Tressel, and Gupta (2008), Beck and Martinez Peria (2010), Gormley (2010), and Balmaceda, Fischer, and Ramirez (2014) offer a less positive view of foreign bank participation by highlighting that foreign banks tend to select borrowers with greater creditworthiness ("cherry pick"), while domestic banks are left with lower quality borrowers. This, in turn can hurt the profitability of the domestic banks and their willingness to lend. Empirical research on the relative performance of domestic and foreign banks has produced contradictory results, with some studies finding that foreign banks do better and other studies reporting stronger performance of domestic banks; see Degryse and Ongena (2008) and Chen and Liao (2011) for reviews of this evidence.

\section{Variables and data}

The empirical model we use to study the relation between foreign bank ownership and bank market power is of the following form:

$$
L_{i t c}=\delta_{0}+\delta_{1} L_{i, t-1, c}+\varphi F O_{i, t-1, c}+\theta F P_{t-1, c}+\delta_{2} B_{i t c}+\delta_{3} X_{t-1, c}+\varepsilon_{i t c} .
$$


In equation (1) the market power $L$ of bank $i$ at year $t$ and country $c$ is regressed on its annual lag, a dummy variable foreign-owned $(F O)$ that is observed at the bank-country-year level and takes the value one when a bank is foreign-owned and zero otherwise, an indicator foreign presence $(F P)$ that is observed at the country-year level and measures the extent of foreign bank presence, ${ }^{2}$ a vector of bank characteristics $B$ observed at the bank-year level, and a vector of variables $X$ observed at the country-year level. $\varepsilon_{i t c}$ is the stochastic disturbance.

Foreign-owned and foreign presence enter equation (1) with a one-year lag in our baseline specifications, and the same holds for all the variables observed at the country-year level. This timing is derived from the fact that country-level changes, like structural, regulatory, and macroeconomic developments, take time to reach the market and have a bearing on the market power of individual banks. In addition, modelling our two foreign ownership variables in this way mitigates the endogeneity problem stemming from reverse causality. In contrast, all the bank-level control variables $B$ enter equation (1) contemporaneously. These variables have a direct and contemporaneous bearing on the cost structure and the pricing decisions of banks, as they describe individual bank strategies that can change in the short-term.

Our final data set includes bank-level data from 131 countries and spans the period 1997-2009 (due to the availability of data for foreign bank ownership). The rest of this section discusses our measures of bank market power, the foreign ownership variables and the control variables used in our study. The correlation coefficients between the explanatory variables that were used as determinants of bank market power do not give rise to any multicollinearity concerns (further left unreported). In Table 1 we provide detailed definitions

\footnotetext{
${ }^{2}$ Given that the correlation coefficient between the two variables is 0.50 , we check whether our estimates suffer from multicollinearity problems. However, the variance inflation and other tests for collinearity imply that this is not the case and that an analysis including both variables is statistically meaningful.
} 
for the variables used to estimate equation (1) and in Table 2 we report summary statistics for these variables.

[Insert Tables 1 and 2 about here]

\subsection{Measures of market power}

The measurement of market power has received much attention in the economics literature since the importance of imperfectly competitive markets was first recognized in the 1930s. The Lerner index (1934) remains to this day a popular measure of market power (and of competition) thanks to its simplicity and transparency. It is defined as:

$$
L_{i t c}=\frac{P_{i t c}-M C_{i t c}}{P_{i t c}},
$$

where $P$ and $M C$ are the price of bank output and the marginal cost of the production of this output. The Lerner index ranges between zero and one, with zero corresponding to perfect competition and larger values reflecting more market power (and less competition). The index can also be negative if $P<M C$, which is of course not sustainable in the long run.

The Lerner index measures departures from the competitive benchmark of marginal cost pricing. This makes it a simple and intuitively appealing index of market power. The index has also often been used as a measure of competition. Although the link between market power and competition might seem obvious, it has been shown that the Lerner index does not always point in the expected direction when competitive conditions change (Stiglitz, 1989; Boone, 2008). For this reason we interpret the Lerner index as primarily a measure of market power, with a further connection to competition a natural but not entirely uncontroversial possibility.

Alternative measures of market power and competition include the H-statistic (Panzar and Rosse 1987) and the profit elasticity (Griffith, Boone, and Harrison, 2005). The H- 
statistic has been widely used in banking studies, but has a shortcoming when it is used as a continuous measure of market power. As Bikker, Shaffer, and Spierdijk (2012) point out, the $\mathrm{H}$-statistic maps the various degrees of market power only weakly and thus cannot be viewed as a continuous variable. The profit elasticity (or Boone indicator) is a relatively new concept that has been used in several recent studies but has also received some criticism. For example, Schiersch and Schmidt-Ehmcke (2010) show that it makes critical assumptions relative to firm size and to market definition.

Given that the alternative indices of market power and competition are still open to some critique, we favor the Lerner index and its variants as our proxy for market power. However, we also employ as robustness checks the H-statistic and the Boone indicator. The main reason for our choice is that the Lerner index allows for variation at the bank level. This advantage increases the richness of our empirical analysis as it allows us to study both the direct impact and the spillover effect of foreign bank ownership and presence. Also, as Beck, De Jonghe, and Schepens (2013) readily argue, the Lerner index is a good proxy for current and future profits stemming from pricing power, while it is not constrained by the extent of the market. In contrast, other bank-level measures, such as the market share or Tobin's q, can lead to larger measurement error because they also capture to a greater extent the rents extracted from being too-big-to-fail. ${ }^{3}$ Moreover, the Lerner index captures both the impact of pricing power on the asset side of the banks' balance sheet and the elements associated with the cost efficiency on their liability side.

Computation of the Lerner index requires knowledge of the marginal cost. When such information is unavailable (as in most empirical data sets), the marginal cost can be estimated using econometric methods. A popular approach has been to estimate a translog cost function and take its derivative to obtain the marginal cost. Some recent work has shown that it is 
possible to improve on this methodology with semiparametric or nonparametric methods that allow for more flexibility in the functional form (McAllister and McManus, 1993; Delis, Iosifidi, and Tsionas, 2014). We follow this new literature and estimate the cost function using a partial linear smooth coefficient (PLSC) model. We provide all the details for the estimation of marginal cost and the data cleaning process in online Appendix A and here we just outline the advantages of this approach. ${ }^{4}$

Most importantly, the semiparametric nature of the method implies that no assumption regarding the functional form of the cost equation is made globally. An assumption is just made "in local neighborhoods of observations." This is important as it is usually quite difficult for the researcher to be certain about the validity of the chosen functional form. In their survey paper, Reiss and Wolak (2007) are very skeptical about using a specific functional form to estimate a cost equation without a prior analysis of the data, since an "incorrect" cost equation can bias the estimation and inference of marginal cost in an unknown direction and with an unknown magnitude. The flexibility of the semiparametric technique also allows using large international samples of banks from different countries, without being concerned that certain banking markets in different countries or banks within the same country face or adopt different production technologies. Hence, this approach takes into account the heterogeneity in the production technology across banks, countries, and time. Delis (2012), Wheelock and Wilson (2012), and Delis, Iosifidi and Tsionas (2014) show that estimation of marginal cost using semiparametric and nonparametric methods produces significantly better results (in terms of lower bias) than parametric techniques and commonly used functional forms like the translog.

\footnotetext{
${ }^{3}$ Even though to a lesser extent, this can also be the case for the Lerner index, in light of governments' policies towards too-big-to-fail banks, especially during times of financial turmoil.

${ }^{4} \mathrm{We}$ check the robustness of our results by using the translog model. We find some deviations in our results that are in line with the study of Delis, Iosifidi, and Tsionas (2014). However, our main results on the effect of foreign bank presence on bank market power are qualitatively similar.
} 
The data used for the estimation of the Lerner index are from Bankscope and require an advanced cleaning process to avoid including duplicates in our sample. This literally involves examining each bank one by one and in many instances collecting information from the banks' websites, for example to examine the history of bank operation and ownership, the existence of subsidiaries with the same names with the parent bank, and the occurrence of M\&As during our sample period. We provide all the details of this intensive data collection and processing in online Appendix A.

We also use two variants of the traditional Lerner index. The first is the efficiencyadjusted Lerner index, which takes the form:

$$
a d j .- \text { Lerner }_{i t c}=\frac{\Pi_{i t c}+T C_{i t c}-M C_{i t c} \cdot Q_{i t c}}{\prod_{i t c}+T C_{i t c}},
$$

where $\Pi$ is the banks' profit and $Q$ is the banks' output, measured by the banks' total earning assets. This index allows for the possibility that firms do not choose the prices and input levels in a profit-maximizing way. For the estimation of this index we use the exact same procedure as Koetter, Kolari, and Spierdijk (2012).

The second variant of the Lerner index adopts a dual-output cost function. Specifically, many banks have a significant volume of off-balance sheet items that can be considered as a distinct output besides the total earning assets that are used as our main output. The off-balance sheet items are produced using essentially the same inputs with the single-output model of the bank and, thus, the single-output model may be missing some important information. For the estimated dual-output cost function and its derivative, see online Appendix A.

In online Appendix B, we report the weighted mean values of the estimated Lerner index by country and year, with market shares as the weights. The equivalent estimates for the adjusted-Lerner index and the dual-output Lerner index are available on request. These values are effectively a new worldwide index of banking-sector competition, with larger 
coverage compared to existing literature. The weighted mean values are $0.27,0.17$, and 0.22 for the Lerner index, the adjusted-Lerner index, and the Lerner index with two outputs, respectively. The Lerner index ranges between -0.12 in Ecuador in 1998 and 0.82 (close to monopoly) in Cuba in 1997. The adjusted-Lerner index ranges between -0.18 in Paraguay in 2002 and 0.82 in Cuba in 1997. We omit the discussion for the Lerner index for the twooutput case, as the results on this index are very similar to the other two Lerner indices. ${ }^{5}$

In Figure 1 we show the time trend in average bank competition for each of the three indices. In broad terms, all indices identify similar trends in competition for the 148 economies over time. More precisely, average bank market power peaks in 2003-2004, declines in the period 2007-2008, and increases again in 2009 and 2010. This pattern may reflect the sharp increase in financial globalization before the financial crisis of 2007 and related reforms that are likely to have led to higher market power through cross-border M\&A's and increased efficiency, without an accompanying reduction in the lending rate. Evidently, the start of the global financial crisis coincides with a decrease in the market power. This may be related to capital losses and non-performing loans suffered by many banks, which reduced efficiency, or to the rising informational asymmetry costs faced by banks during crises (e.g., adverse selection and moral hazard) that sharply increase the real cost of lending.

[Insert Figure 1 about here]

\subsection{Foreign bank ownership}

\footnotetext{
${ }^{5}$ Our country-averages for the Lerner index are very close to the equivalent from the World Bank (overall averages are 0.22 and 0.21 , respectively). Even though there are some relatively minor differences between the countries, the correlation coefficient between the two is as high as 0.67. Most countries with high (low) Lerner indices based on our estimates also have high (low) Lerner indices in the respective indices of the World Bank. Sensitivity analysis using the World Bank estimates confirms the main findings of our study.
} 
Information for foreign bank ownership is from the database of Claessens and van Horen (2014). As we follow their approach in our own data processing to estimate bank market power, we have an almost identical sample of banks that we identify as foreign or domestic owned. Foreign-owned banks are identified as those with $50 \%$ or more of their shares owned by foreigners and we use this information to construct the foreign-owned dummy variable. This variable identifies the direct effect of foreign ownership on the market power of individual banks.

For the country-level foreign presence, Claessens and van Horen (2014) construct two indices. The first index is defined as the percentage of foreign banks among total banks in a country (foreign presence) and covers the period 1995 to 2009 . The second is defined as the percentage of foreign bank assets among total bank assets (foreign presence in terms of assets). Even though the second index can be argued to describe foreign bank presence somewhat better, it is only available for the 2004-2009 period because of missing information on bank assets for a large number of banks before 2004. The correlation coefficient between the two indices for the period 2004-2009 is as high as $81.1 \%$. Thus, the large time span of the data set makes the use of the first index optimal for our study, whereas the index based on the market share of foreign banks is used in a sensitivity analysis.

By using foreign presence in the same equation with foreign-owned we are able to identify the separate impact of the two on banks' market power. Figure 2 presents a scatter plot of the Lerner index against foreign presence and the associated regression line. The regression line has a positive slope that is statistically significant at the $1 \%$ level. It remains to be examined whether this relation continues to hold when controlling for foreign-owned and whether it can be interpreted as causal.

[Insert Figure 2 about here] 


\subsection{Control variables}

Consistent with previous studies, we include several control variables that are drawn from the literature on the determinants of bank competition to rule out other possible explanations for our results (e.g., Claessens and Laeven, 2004; Beck, Demirgüç-Kunt, and Levine, 2006; Delis, 2012). The bank-specific variables (indicated as $B_{i t c}$ in equation 1) include: the ratio of customer deposits to total assets (termed deposits) to control for the level of bank deposits supporting total assets; the ratio of the book value of equity capital to total assets (capitalization) to control for bank capitalization; the ratio of loans to total assets (loans) to control for bank specialization (also used as a crude measure of liquidity); and the natural logarithm of real total assets (bank size) to measure bank size. Delis (2012) shows that wellcapitalized and larger banks are able to set higher margins or to have access to cheaper sources of funds due to scale economies and lower informational asymmetries. In contrast, a higher deposits ratio implies higher cost of intermediated funds and, thus, lower market power (especially in normal economic periods). In turn, loans is a measure of bank specialization, with a higher ratio relating to banks that focus on the traditional activity of credit provision.

We additionally assess the robustness of our results to the use of other measures of bank liquidity (liquid assets divided by total assets) and credit risk (non-performing loans divided by total loans or loan loss provisions divided by total loans), but we did not find significant changes in our results. It should be noted that the sample is smaller when including the last two variables, due to missing data, and that the definition of liquid assets in Bankscope sometimes differs across countries.

For the country-level characteristics we use a wide set of structural, regulatory, institutional, and macroeconomic variables. First, we use the entry restrictions index, which 
measures the degree to which all banks in a country face entry barriers. We construct this index using information from the studies of Barth, Caprio, and Levine (2008), Cihak, Demirgüç-Kunt, Martinez Peria, and Mohseni-Cheraghlou (2012), and previous versions of the former study (henceforth jointly indicated as BCL2008; details are provided in Table 1). This index takes a value from zero to 12 , with larger values denoting more stringent entry restrictions.

We also use the relative share of privately owned banks $v s$. that of the publicly owned banks (constructed in terms of deposits). This allows avoiding to falsely attribute the impact of foreign bank ownership (which usually corresponds to private ownership), to the associated impact of private ownership on banks' market power. We note that poorer countries are associated with higher levels of public ownership of banks, which is consistent with the findings of La Porta, Lopez de Silanes, and Shleifer (2002). Further, we use the Herfindahl-Hirschman index, which is defined as the ratio of the sum of squared market shares of each bank in the industry. Market concentration measures, such as the HerfindahlHirschman index, have been considered in the past as measures of competition (Cetorelli and Strahan, 2006). There is now consensus that these indices are not accurate proxies of competition but they are nonetheless useful control variables as they reflect important industry characteristics (Claessens and Laeven, 2004; Beck, Demirgüç-Kunt, and Levine, 2006).

Another important set of characteristics that can potentially influence the relation between market power and foreign bank ownership relates to the regulatory framework in which banks operate (Claessens and Laeven, 2004; Beck, Demirgüç-Kunt, and Levine, 2006). We use three indices obtained (once more) from BCL2008. These indices represent activity restrictions, capital requirements, and supervisory power. Explicit definitions of these indices 
are provided in Table 1. For a literature review of the relation between bank competition and regulation, see for example Degryse and Ongena (2008).

Moreover, we control for the impact of the macroeconomic environment common to all banks that can potentially affect competitive conditions. We use the share of the manufacturing sector relative to GDP (manufacturing) and the net inflow of foreign direct investment $(F D I)$. Cetorelli and Strahan (2006) suggest that the manufacturing sector is highly bank-dependent and the conditions in this industry can affect the market power of banks through both demand and supply forces. Clarke, Cull, Martinez Peria, and Sanchez (2003) provide evidence suggesting that foreign banks follow their clients abroad. Thus, the effect of foreign bank ownership on the banks' market power might be overestimated when the net inflow of FDI and manufacturing are excluded from the analysis.

In addition, we use information from the Heritage foundation on the size of the public sector, as measured by the ratio of government spending to GDP (government spending). Following the reasoning of La Porta, Lopez de Silanes, and Shleifer (2002), countries with a larger public sector are relatively inefficient, governments are interventionist, and protection of property rights is poor. Thus, we could observe a positive link between this measure of government size and banks' market power.

Along the same lines, we use the financial freedom index and the trade freedom index from the Heritage foundation. The financial freedom index measures independence from government control and interference in the financial sector. Higher values for this index reflect greater financial liberalization. ${ }^{6}$ The trade freedom index is a composite measure of the absence of tariff and non-tariff barriers that affect imports and exports of goods and services, with higher values indicating more freedom to trade internationally.

\footnotetext{
${ }^{6}$ An alternative index has been constructed by Abiad, Detragiache, and Tressel (2010) but its coverage ends in 2005.
} 
We also control for the prevailing political ideology and freedom using the ideology of chief executives variable (left, center, or right) from Beck, Clarke, Groff, Keefer, and Walsh (2001) (updated until 2012) and the polity variable from the Polity IV project, respectively. These two variables are potentially important in explaining the competitive conditions in the banking sector, because banks operating in more democratic and more rightwing countries will have fewer restrictions that might not be captured by our regulatory variables. Finally, we control for the level of economic development by including the natural logarithm of GDP per capita, taken from the World Bank Indicators. ${ }^{7}$

\section{Foreign bank ownership and market power: Identification and results}

\subsection{Empirical identification}

Two important identification problems are the dynamic nature of bank market power and the potential endogeneity of the foreign ownership variables. Concerning the former, Berger, Bonime, Covitz, and Hancock (2000) and Goddard, Molyneux, and Wilson (2004) suggest that even developed banking markets might be characterized by information opacity, networking, and relationship-lending, all of which impede competition. These elements cause persistence in the cost structure, profitability, and market power of banks.

To account for these dynamics we include the first and/ or the second lag of the dependent variable among the regressors and use the GMM estimators for dynamic panels of Arellano and Bond (1991) and Blundell and Bond (1998). In our analysis we use the two-step "difference" GMM estimator with robust standard errors corrected using the method of Windmeijer (2005). ${ }^{8}$ The consistency of the GMM estimator depends both on the assumption

\footnotetext{
${ }^{7}$ We exhaustively control with more than two hundred other variables taken from various databases. But we do not find any significant changes in the main results we report here. We therefore think our estimates are conservatively robust.

${ }^{8}$ We prefer the so-called "difference" over the "system" GMM estimator because the results on the specification tests (i.e., the Hansen tests of overidentifying restrictions and tests for serial correlation of the error terms) are better under the former method. Specifically, we find that the lagged differences used as instruments under the
} 
of the validity of the instruments and on the assumption that the error term does not exhibit serial correlation. To this end, we use two tests proposed by Arellano and Bond (1991) to evaluate these assumptions. The first is the Hansen test of over-identifying restrictions, which tests the overall strength of the instruments. The second test examines the assumption of no serial correlation in the error terms.

Note that the error term obtained from the estimation of equation (1) is likely to be serially correlated due to the fact that the dependent variable is observed at the bank-countryyear level and some of the explanatory variables are observed at the country-year level. This problem is comprehensively analyzed by Moulton (1990). Thus, estimation is carried out using standard errors clustered by country. We also experiment with country-specific year effects, but this increases the number of instruments in the GMM procedure asymptotically and causes the Hansen test to be equal to unity.

In estimating equation (1), endogeneity of the two foreign ownership variables can arise both from reverse causality and omitted variable bias. Reverse causality could emerge from the preference of foreign-owned banks to enter with monopolistic products with high markups, so as to generate higher profits. In addition, it can arise if foreign banks acquire banks that already possess market power and continue similar practices. However, the monopolistic product explanation is more likely in our sample, given that the mean market power of the acquired banks (0.203) is on average lower than that of the non-acquired domestic banks (0.218). To alleviate these concerns of reverse causality, all the right-hand side variables except the bank characteristics are lagged once. This is intuitive both statistically and theoretically. From a statistical viewpoint, the literature commonly (e.g., recently Beck, De Jonghe, and Schepens, 2013) employs lagged explanatory variables to mitigate endogeneity issues that emerge due to reverse causality. On the theoretical side, the 
banks are aware of their main balance-sheet characteristics when deciding on their cost structure and pricing policy (i.e., the components of the Lerner index).

In turn, the omitted variable bias could arise because there are some unobservable reasons affecting banks' market power and these may correlate with the choice of a bank to enter into a specific market (e.g., specific unobserved elements of the tax system, ability to carry out profit shifting and/or portfolio diversification). We assuage the omitted variable bias by using an IV-style instrumental variable. Specifically, we use the entry restrictions for foreign banks $(E R F B)$ lagged once as an IV-style instrument. We construct this index with information from BCL2008 (see again Table 1 for details). This index ranges between zero and four inclusive, with higher values reflecting higher entry restrictions for foreign banks. We identify the two endogenous variables by using both $E R F B_{\mathrm{t}-1}$ and $E R F B_{\mathrm{t}-2}$ as IV-style instruments.

Naturally, the entry restrictions for foreign banks affect foreign bank ownership and presence in each country: we hypothesize that foreign bank presence must be lower in countries with significant protection of the domestic banking sector. Further, it seems unlikely that these restrictions affect banks' market power directly. The only way that ERFB could be correlated with the Lerner indices is through common regulatory, institutional, and macroeconomic developments that tend to move together. However, as discussed in Section 3.3, in our empirical analysis we control for a number of such variables, and most importantly for the general entry restrictions common to all banks, foreign-owned or not. Thus, we distinguish between entry restrictions for foreign banks and general entry restrictions. We also control for year fixed effects, and other regulatory, macroeconomic, institutional, and political variables. ${ }^{9}$

\footnotetext{
industry, see Bruno and Hauswald (2013).

${ }^{9}$ In online Appendix D we run additional tests for the validity of the $E R F B$ variable as an instrument as follows. First, we regress, using the fixed effects model, the two foreign ownership variables on the $E R F B$ variable plus controls and we find that $E R F B$ is negative and strongly statistically significant. Also, we regress, again with the
} 
Some of the control variables can also be considered as endogenous in equation (1) due to an omitted variable bias. Not recognizing these variables as such can bias the coefficient on the foreign ownership variable. GMM allows treating these variables as endogenous using lags of the instrumented variables as instruments (Bond, 2002; Beck, Demirgüç-Kunt, and Levine, 2006; Roodman, 2009). We adopt this strategy despite its imperfections because finding solely economically motivated instruments for all potential endogenous control variables would be challenging. We choose the lag-length of these instruments on the basis of the Hansen test of overidentifying restrictions.

In light of the above, the full set of the instrumental variables in the baseline specification includes the contemporaneous and the first lag of the entry restrictions for foreign banks as IV-style instruments, and, as GMM-style instruments, the third lag of the dependent variable, the first lags of the bank-specific control variables and the second to fourth lags of entry restrictions. In the specifications with additional controls we also add the second lags of these control variables as GMM-style instruments. Use of these instruments yields Hansen tests for both the overall and IV-style instruments that do not reject the null of overidentifying restrictions. We also examine the sensitivity of our results with even fewer instruments to avoid the too-many instruments problem highlighted by Roodman (2009). Our results are essentially unchanged. We also confirm, using the second-order autocorrelation test (reported as AR2), that our estimated equations do not suffer from serial correlation.

\subsection{Baseline results}

In Table 3 we report the baseline results from the estimation of equation (1). The Hansen tests (overall and IV-style) show that the estimated equations are not overidentified and the

fixed effects model, the market power variables on the $E R F B$ plus the same controls and we find that $E R F B$ is statistically insignificant. 
AR2 test that there is no second-order autocorrelation. As expected, the values of the coefficient on the lagged dependent variable indicate that market power is quite persistent.

[Insert Table 3 about here]

The specifications in Table 3 include different measures of market power. In column I we use the most basic Lerner index and we find that the coefficient of foreign-owned is statistically insignificant. This result shows that the average foreign bank in our sample does not have a significantly higher Lerner index compared to the average domestically owned bank. In contrast, foreign presence has a positive and statistically significant (at the $5 \%$ level) effect on the Lerner index. This effect is also economically significant. For example, an increase in foreign bank presence by $8 \%$ p (percentage points) from $17 \%$ in 1997 to $25 \%$ in 2009 (which is the increase observed for the average country in our baseline specification) resulted in an increase in the Lerner index of 0.07 points (for the average Lerner index in our sample of 0.22 this is equivalent to a $32 \%$ increase). Considering that the standard deviation of foreign presence is $17 \% \mathrm{p}$ and the trend on this variable is indeed increasing, it seems that the share of foreign banks is a very important explanatory factor of the bank-level markups.

In column II we assess the inclusion of foreign presence in terms of assets to examine the spillover effect (instead of foreign presence). The coefficient on this variable is positive and statistically significant at the $1 \%$ level. The economic significance however is lower compared to foreign presence. This is expected because the assets-based variable incorporates the element that foreign banks can also be partially owned by domestic owners, whereas foreign presence characterizes foreign banks entirely as foreign-owned or not. Still a $10 \% \mathrm{p}$ increase in foreign bank ownership in terms of assets will increase the Lerner index by 
0.03. For the bank in our sample with an average Lerner index this implies an $13.6 \%$ increase in the Lerner index.

In columns III and IV we carry out the same analysis by using Lerner indices obtained when capitalization is included in the cost function and when, in addition to the inclusion of capitalization, the cost function also includes country fixed effects. Compared to column I, the results from both specifications remain practically unaffected. In columns V and VI we further experiment with the adjusted-Lerner and the dual-output Lerner indices and we still find that the only statistically significant ownership variable is foreign presence. These results also hold when we use the country-year average of the Lerner index (column VII), the translog-based country-year average Lerner index from the World Bank (column VIII), and the country-year Boone indicator from the World Bank (column IX). In contrast, the results are inferior when we use the $\mathrm{H}$-statistic, either at the bank-level as in column $\mathrm{X}$ or at the country-year level as in column XI. ${ }^{10}$

The implications of these results are then straightforward. The ownership status, foreign or domestic, of individual banks seems to play no role in explaining banks' market power. Thus, we can rule out a significant direct effect of foreign-owned on bank market power, but we do find a positive and significant spillover effect of foreign presence on bank markups.

The effect of the control variables is in line with expectations and with previous studies. For example, Barth, Caprio, and Levine (2004) find that higher entry restrictions in banking markets are associated with a greater ability for the banks to charge a price above its marginal cost. In our sample we identify the same effect through the entry restrictions variable. We also find that well-capitalized banks are those possessing higher market power,

\footnotetext{
${ }^{10}$ The inferior findings on the regressions including the $\mathrm{H}$-statistic compared to the rest of the specifications on the Lerner and Boone indices may reflect the fact that from the three measures of market power, the H-statistic is the only one that does not robustly map the various degrees of market power (e.g., Bikker, Shaffer, and Spierdijk, 2012).
} 
which can be attributed to their ability to raise capital more easily and perhaps more inexpensively. In contrast, banks with higher deposits have lower market power in some of our baseline specifications. This is consistent with the fact that the higher cost of deposits relative to other sources of bank funds, implies lower market power, probably because the marginal cost is higher.

We also consider in our baseline specifications the effect of the economic development (as measured by the GDP per capita) and we find that it is associated with lower Lerner indices in our preferred models (columns I-III). Thus, it seems that banks in countries with lower economic development benefit from higher price-cost margins, a result in line with Delis (2012). In online Appendix C1 we report the results from the addition of many other structural, institutional, and macroeconomic variables. Our main results on the effect of the foreign ownership variables remain unaffected.

The findings reported in Table 3 and online Appendix C1 are in contrast with the two existing studies on this issue (Claessens and Laeven; 2004; Jeon, Olivero, and Wu, 2011) that document a negative effect of foreign bank presence on market power measured at the country level. In online Appendix $\mathrm{C} 2$ we identify the main reason behind this different finding. In column I we report the results from a cross-sectional sample (year-averages for each country over the period 1997-2004 including the same countries with Claessens and Laeven (2004). ${ }^{11}$ We use the same explanatory variables with this study and the same estimation method (OLS with robust standard errors). We are indeed able to (almost) exactly replicate their results on the foreign bank presence variable both in terms of sign and magnitude. Subsequently, we aggregate our Lerner index across the same set of countries and years and we find that the results also predict a negative relation between foreign bank

\footnotetext{
${ }^{11}$ Claessens and Laeven (2004) use data for the period 1994-2001. Given that we do not have data on market power prior to 1997, we replicate their findings using the period 1997-2004.
} 
presence and market power. Thus, the findings of Claessens and Laeven (2004) are not due to the measure of market power.

Subsequently, in column III we allow the Lerner index to vary at the bank level and we use again the countries included by Claessens and Laeven over the period 1997-2004. Thus, in this regression the Lerner index is identified at the bank-country-year level as in our baseline specification in Table 3. We use the GMM estimator, but the results are robust to the use of OLS with bank fixed effects. The results change completely and are in line with those of Table 3. Thus, we confirm that the difference in our findings compared to the study of Claessens and Laven (2004) is mainly due to the higher dimension of our data. ${ }^{12}$

Intuitively, the increased foreign bank presence can increase the market power of banks for at least three reasons. First, Herrero and Martinez Peria (2007) found that foreign banks penetrate those banking sectors with profit opportunities. Usually the old regime of these sectors consists of banks with low-quality technology that are relatively cost-inefficient or misprice risk (Peek, Rosengren, and Kasirye, 1999). In these situations, foreign banks are better able to price risk through their technological advantage, and this leads to higher intermediation margins via higher intermediation prices (Havrylchyk and Jurzyk, 2011). Claessens (2006), suggest that this effect is then carried over to the domestic banks, which will follow the new pricing schemes because they will, in time, gain access to the new technology (i.e., resulting in a technology spillover effect of know-how). Second, foreign banks tend to lend to more creditworthy clients. From the demand side, these borrowers might be willing to pay higher margins, if they perceive foreign banks as less risky. Third,

\footnotetext{
${ }^{12} \mathrm{We}$ also try to replicate the results by Jeon, Olivero, and $\mathrm{Wu}$ (2011). Their $\mathrm{H}$-statistics are unavailable to us and thus we use our bank-level estimates of the $\mathrm{H}$-statistic (used in column X of Table 3) to produce countryyear aggregates for the countries and years in their study. However, the foreign bank presence variable is not a statistically significant determinant of the thusly constructed $\mathrm{H}$-statistic. We also tried to re-estimate the country-year H-statistic parametrically using the methodology described in their study. We find that their nonlinear estimator does not converge in our country-specific samples. Finally, we use the random coefficient estimation approach of Swamy (1970) to produce the country-year H-statistics, but again the resulting measure is not significantly explained by foreign bank presence. These results are available on request.
} 
foreign banks have the ability to offer new banking products compared to domestic banks. Thus, they become the monopolists in these products, at least for some time.

\subsection{Heterogeneity in the results}

In this section we examine the driving forces of the positive effect on foreign presence on banks' market power, by following the changes in the effects over time, and by differentiating between the components of the Lerner index (price vs. marginal cost), the mode of foreign bank entry (greenfield vs. M\&A), and the period in question (pre- vs. postcrisis). In most of the analysis, we focus on the effect of foreign presence, which is the only foreign-ownership variable that carries a significant coefficient in Table 3.

First, we follow the changes in the market power of foreign banks over time in a more systematic way. We begin by considering the potential heterogeneity in the coefficient on foreign presence based on the time (years) since the foreign bank presence reached a specific threshold. The rationale for including this variable is that the longer it takes foreign banks to dominate in a new market, the more acquainted they become with domestic practices and clientele, thereby facing lower informational and agency costs. To this end, we introduce interaction terms between the years in which foreign presence reached values equal to $40 \%$ and 50\%, respectively, and we present the estimation results in columns I and II of Table 4. A $50 \%$ threshold naturally captures the presence of a clear majority of foreign-owned banks at the country-year level. The $40 \%$ threshold exercise then shows what happens as we move from a lower (40\%) to a higher (50\%) decile.

We find a positive and marginally statistically significant (at the $10 \%$ level) interaction term in both regressions. Therefore, our findings suggest that the longer a country has high levels of foreign bank presence, the higher the positive impact of foreign bank presence on banks' market power. 
[Insert Table 4 about here]

In column III of Table 4 we additionally include the third lag of foreign presence to examine how the estimation results evolve over time. This is a test of whether the positive effect of foreign presence will fade over time. The results show that this is not the case. The first lag used all along in our empirical analysis is the only one that retains a positive and statistically significant coefficient. We do not include the second lag of foreign presence because the results are clearly driven by collinearity (the pairwise correlation coefficient between the first and the second lags of foreign presence is equal to 0.99). We also experiment with the inclusion of the fourth and the fifth lags, but these estimates are again statistically insignificant. In column IV we report the results from the equivalent exercise with the foreign-owned variable. The coefficient estimates on all the lags of this variable are statistically insignificant.

We also take one additional step and carry out an event-type analysis to examine the timeliness of the effect of the foreign ownership variables. Specifically, in a similar fashion to Peristiani (1997), we regress the change in foreign bank ownership in the year following the event of foreign bank entry on a dummy variable that takes the value one in the year the foreign bank enters the market. We use a treatment effect model, where the dummy variable is endogenous and again the entry restrictions for foreign banks is our instrument. The results, reported in column $\mathrm{V}$, are equivalent to those of the previous analysis, showing that foreign presence is the only significant foreign ownership variable one year after the entry. When we use a two-year time window after the event, both the foreign ownership variables become insignificant (column VI). The same holds for longer time windows for market power. This finding implies that the "spillover effect" is undeniably a short-term effect. 
Whether this effect truly weakens after the first year of course requires a deeper investigation, given that other corporate events might bias the estimates.

In Table 5 we look at the effect of foreign bank ownership on the separate components of the Lerner index. In column I we replicate column I of Table 3, this time using the price of bank output as our dependent variable, while in column II we use the marginal cost as our dependent variable. We find that the only significant effect (at the $10 \%$ level) is than of foreign presence on marginal cost. Equivalently, in column III the results show that the effect of foreign presence on the Lerner index is due to the increase in the gap between the price and marginal cost (i.e., the numerator of the Lerner index). Thus, the main mechanism driving the increase in the market power of banks relates to the cost-efficiency advantage of the foreign banks, which forces domestic banks to also become more efficient. However, this increase in efficiency is not accompanied by a significant reduction in the lending rates for the average bank.

[Insert Table 5 about here]

In Table 6 we look into the role of the mode of entry of foreign banks, greenfield or through M\&As, on the positive nexus between foreign presence and market power. The table includes the same set of control variables with column I of Table 3 (and Table 5), but we do not include these estimates due to space considerations. Column I reports the results from a specification that includes an interaction term between foreign presence and the variable named country $M \& A s$. This variable equals the number of foreign owned banks that enter in the host country through an M\&A over the total number of foreign-owned banks, scaled from zero to one for expositional brevity. In our sample, two out of three foreign banks enter our sample through an M\&A. To provide inference at the mean of the main effects, we mean- 
center the variables used to construct interaction terms. The main effect of the foreign presence comes out positive and statistically significant as before. The interaction effect is also positive and statistically significant at the $5 \%$ level, indicating that entry through M\&As is one of the main causal factors of the positive relation between foreign presence and Lerner. Thus, greenfield entry of foreign banks, along with an equally capitalized domestic banking sector, seems to be the sine qua non to avoid the buildup of market power.

[Insert Table 6 about here]

In column II of Table 6 we examine how the incumbent domestic banks react to foreign bank entry via greenfield or M\&As. We find that the results are almost identical with those of column I, with the exception that the main effect of foreign presence is statistically insignificant at conventional levels. Thus, this regression equation shows that the positive effect of foreign presence on incumbent domestic banks only comes from the entry of foreign banks through M\&As. In this sense, our results are in line with DeYoung, Hasan, and Kirchhoff (1998) who find that the cost efficiency of local banks improves in response to increased entry in states, which had been allowing out-of-state entry for some considerable period of time, as well as with Evanoff and Ors (2008) who receive similar results for a larger time frame. In column III we further experiment with the country-year average Lerner index by carrying out the same analysis. The result on foreign presence is identical to column I while the interaction effect is positive but statistically significant at the $10 \%$ level, indicating that the foreign bank entry through M\&As is the main transition mechanism for the positive effect even in country-level regression.

The main question arising from the exercises of Tables 5 and 6 is whether the higher market power of the foreign banks entering through an M\&A is price- or efficiency-based. In 
columns IV to VI of Table 6 we replicate the results of Table 5, using as dependent variable the price of bank output, marginal cost and the price-cost margin in columns IV, V and VI, respectively when including the interaction term of column I. Again, the results show that changes are mainly driven by reductions in the marginal cost due to the increased foreign presence of banks entering through M\&As (column VI). Also, for a value of country $M \& A s$ equal to this variable's average (0.72), the derivative $d$ (Marginal cost) / $\mathrm{d}$ (Foreign presence) equals 0.0027 , which is very close to the value of 0.0023 found in column II of Table 5.

These findings are quite important and have specific implications in relation with the existing literature. As in Bonin, Hasan, and Wachtel (2005) and Degryse, Havrylchyk, Jurzyk, and Kozak (2012), foreign banks mainly acquire domestic banks with high cost inefficiency and the new bank, after the M\&A, tends to reduce marginal costs, which increases the gap between the output price and the marginal cost. Note, however, that there is no loss in allocative efficiency in this scenario: bank customers keep paying the same prices, total output does not decline, and wealth is transferred from bank suppliers to bank owners.

Further, we have to keep in mind that there is a reason for the acquisition. Even in developed countries, the acquired bank usually is a low-performance institution or a government-owned one with no clear profit-maximizing objective (Berger, Clarke, Cull, Klapper, and Udell, 2005). In the same vein, a recent strand of the literature (Martinez Peria and Mody, 2004) suggests that cross-border M\&As in banking are value destructing because of the high inefficiency of the acquired domestic banks. The new bank entering through an M\&A will lower costs, giving rise to higher Lerner indices. In turn, the local-incumbent banks react with similar strategies and hence the comparative advantage of the foreign banks quickly erodes over time. This scenario is indicative of the insignificant direct effect. In contrast, the increased foreign presence tends to increase the overall market power and, hence, generates a significant spillover effect. 
An interesting extension of the empirical analysis is to consider the potential structural break in the relation between foreign bank presence and market power caused by the financial crisis of 2007. A recent strand of the literature suggests that foreign banks do not necessarily enjoy the financial support of their parent institutions during the financial crisis (De Haas and Van Lelyveld, 2014) or that foreign banks become even more selective in directing their lending to financially sounder local firms (Pennathur and Vishwasrao, 2014). In columns I and III of Table 7 we report our baseline results for the pre- and post-crises periods, respectively (before and after 2007). We find that the coefficients on foreign presence are positive and statistically significant in both periods and that the economic significance is somewhat higher in the post-crisis period. Thus, the nexus between foreign bank presence and market power becomes somewhat stronger after 2007. Again, the main source of this finding is foreign bank entry through M\&As. This is reflected in the larger coefficient of the relevant interaction term in column $\mathrm{V}$ (post-crisis period) relative to the respective one in column II (pre-crisis period).

\section{[Insert Table 7 about here]}

We consider various other analyses to examine the heterogeneity in our baseline results based on the theoretical considerations discussed in Section 2. First, we examine whether our results on the foreign ownership variables change with the level of economic development, by either introducing relevant interaction terms of the foreign ownership variables or examining each income group separately. The differences in findings are negligible Second, we introduce an interaction term between foreign-owned and foreign presence. This would allow to see whether the spillover effect is similar across the domestic and foreign banks. We find that this interaction term is statistically insignificant, showing that 
domestic and foreign banks are perfect substitutes in this process. Third, we hypothesize that the impact of foreign bank ownership on the market power of banks depends on differences in banking-system institutions between the host and the origin country (Mian, 2006). We consider difference in (i) restrictions on banks to own non-financial firms, (ii) entry barriers on banks, (iii) regulations in terms of the summation of the three previous regulatory characteristics, (iv) geographical distance between the capitals of the two countries, (v) institutions (information sharing, credit rights and property rights), (vi) culture, (vii) bankingindustry concentration, and (viii) financial-statement transparency. However, we do not find robust evidence in favor of these hypotheses.

\section{Conclusions}

This paper analyzes the impact of foreign bank ownership on the market power of individual banks. We collect bank-year data for all countries in the world to estimate the market power of banks through the use of the Lerner index. We use a cost function with a semiparametric technique that allows for a very flexible specification and does not impose a specific functional form on the data. Our method yields observation-specific estimates of the Lerner index.

Subsequently, we match our data set with that of Claessens and van Horen (2014) who have information on foreign bank ownership. Thus, our final sample includes information for banks from 131 countries over the period 1997-2009. Using this data set we examine the impact of the ownership status (foreign or domestic) of individual banks on their market power (direct effect), as well as the impact of the share of the number of foreignowned banks to the total number banks in the industry (spillover effect).

We find that the only significant impact comes from the spillover effect and that this effect is positive in the sense of a higher bank market power due to an increased foreign bank 
presence. This effect is mainly transmitted through the considerably higher incidence of foreign bank entry through M\&As, instead of greenfield entry. We also find that the positive impact of the country-level trends in foreign bank presence on banks' market power is mainly driven by a decrease in the marginal cost (a cost-efficiency effect).

These results have important policy implications for regulators and policy makers alike. If increased competition is the requirement, then it seems imperative that foreign bank entry is made through greenfield entry. Further, a concomitant abolition of entry barriers is warranted. If, in contrast, competition is already rather strong and there are concerns about the stability of the banking system, the foreign bank entry through M\&As and the protectionist policies are preferable to increase the market power of banks and their rents. Thus, a natural extension to our work would be to examine the real effects behind the positive nexus of foreign bank presence with banks' market power. In particular, bank market power is usually linked to increased lending rates and, thus, to reduced welfare. Yet, a higher market power of banks increases bank profitability and can lead to increased financial stability. Given our findings, the special role of foreign bank presence in the bank market powerstability relation needs further examination. We leave this and other issues for future research. 


\section{References}

Abiad, Abdul, Enrica Detragiache, and Thierry Tressel. (2010) “A New Database of Financial Reforms.” IMF Staff Papers, 57, 281-302.

Arellano, Manuel, and Stephen Bond. (1991) "Some Tests of Specification for Panel Data: Monte Carlo Evidence and an Application to Employment Equations." Review of Economic Studies, 58, 277-97.

Balmaceda, Felipe, Ronald R. Fischer, and Felipe Ramirez. (2014) "Financial Liberalization, Market Structure and Credit Penetration.” Journal of Financial Intermediation, 23, 4775.

Barth, Jame R., Gerard Caprio, and Ross Levine, (2001) "The Regulation and Supervision of Banks Around the World: A New Database." In Integrating Emerging Market Countries into the Global Financial System, edited by Robert E. Litan and Richard J. Herring, pp 183-241. Brookings-Wharton Papers on Financial Services: Brookings Institution Press.

Barth, Jame R., Gerard Caprio, and Ross Levine. (2004) "Bank Regulation and Supervision: What Works Best?” Journal of Financial Intermediation, 13, 205-248.

Barth, Jame R., Gerard Caprio, and Ross Levine. (2008) "Bank Regulations are Changing: For Better or Worse?” Comparative Economic studies, 50, 537-563.

Beck, Thorsten, George Clarke, Alberto Groff, Philip Keefer, and Patrick Walsh. (2001) "New Tools and New Tests in Comparative Political Economy: The Database of Political Institutions.” World Bank Economic Review, 15, 165-176.

Beck, Thorsten, Asli Demirgüç-Kunt, and Ross Levine. (2006) "Bank Concentration, Competition, and Crises: First Results." Journal of Banking and Finance, 30, 15811603. 
Beck, Thorsten, Vasso Ioannidou, and Larissa Schafer. (2012) "Foreigners vs. Natives: Bank Lending Technologies and Loan Pricing.” European Banking Center Discussion Paper 2012-014.

Beck, Thorsten, Olivier De Jonghe, and Dlenn Schepens. (2013) "Bank Competition and Stability: Cross-Country Heterogeneity." Journal of financial Intermediation, 22, 218244.

Beck, Thorsten, and Maria S. Martinez Peria, (2010) "Foreign Bank Participation and Outreach: Evidence from Mexico.”Journal of Financial Intermediation, 19, 52-73.

Berger, Allen N., Seth D. Bonime, Daniel M. Covitz, and Diana Hancock. (2000) "Why are Bank Profits so Persistent? The Roles of Product Market Competition, Informational Opacity, and Regional/Macroeconomic Shocks." Journal of Banking and Finance, 24, 1203-1235.

Berger, Allen N., George R.G. Clarke, Robert Cull, Leora Klapper,, and Gregory F. Udell,. (2005) "Corporate Governance and Bank Performance: A Joint Analysis of the Static, Selection, and Dynamic Effects of Domestic, Foreign, and State Ownership." Journal of Banking and Finance, 29, 2179-2221.

Berger, Allen N., Iftekhar Hasan, and Leora F. Klapper. (2004) "Further Evidence on the Link Between Finance and Growth: An International Analysis of Community Banking and Economic Performance.” Journal of Financial Services Research, 25, 169-202.

Bikker, Jacob A., Sherrill Shaffer, and Laura Spierdijk. (2012) "Assessing Competition with Panzar-Rosse Model: The Role of Scale, Costs, and Equilibrium." The Review of Economics and Statistics, 94, 1025-1044.

Blundell, Richard, and Stephen Bond. (1998) "Initial Conditions and Moment Restrictions in Dynamic Panel Data Models.” Journal of Econometrics, 87, 115-143. 
Bofondi, Marcello, and Giorgio Gobbi. (2006) "Informational Barriers to Entry Into Credit Markets." Review of Finance, 10, 39-67.

Bonin, John, Iftekhar Hasan, and Paul Wachtel. (2005) "Bank Performance, Efficiency and Ownership in Transition Countries.” Journal of Banking and Finance, 29, 31-53.

Bond, Stephen. (2002) "Dynamic Panel Data Models: A guide to Microdata Methods and Practice.” Portuguese Economic Journal, 1, 141-162.

Boone, Jan. (2008) "A New Way to Measure Competition.” The Economic Journal, 118, $1245-1261$.

Brissimis, Sophocles N., and Manthos D. Delis. (2011) "Bank-Level Estimates of Market Power.” European Journal of Operational Research, 212, 508-517.

Bruno, Valentina, and Robert Hauswald. (2013) “The Real Effect of Foreign Banks.” Review of Finance, 17, 1-34.

Cetorelli, Nicola, and Philip E. Strahan. (2006) "Finance as a Barrier to Entry: Bank Competition and Industry Structure in Local U.S. Markets.” Journal of Finance, 61, 437-461.

Chen, Sheng-Hung, and Chien-Chang Liao. (2011) "Are Foreign Banks More Profitable Than Domestic Banks? Home- and Host-country Effects of Banking Market structure, Governance, and Supervision.” Journal of Banking and Finance, 35, 819-839.

Cihak, Martin, Asli Demirgüç-Kunt, Maria S. Martinez Peria, and Amin MohseniCheraghlou. (2012) "Bank Regulation and Supervision Around the World: A Crisis Update.” World Bank Policy Research Working Paper 6286.

Claessens, Stijn. (2006) “Competitive Implications of Cross-Border Banking.” World bank policy research working paper series 3854 . 
Claessens, Stijn, Asli Demirgüç-Kunt, and Harry Huizinga. (2001) “How Does Foreign Bank Entry Affect Domestic Banking Markets?” Journal of Banking and Finance, 25, 891911.

Claessens, Stijn, and Luc Laeven. 2004. "What Drives Bank Competition? Some International Evidence.” Journal of Money, Credit, and Banking, 36, 563-583.

Claessens, Stijn, and Neeltje Van Horen. (2014) "Foreign Banks: Trends and Impact." Journal of Money, Credit and Banking, 46, 295-326.

Clarke, George, Robert Cull, Maria S. Martinez Peria, and Susana M. Sanchez. (2003) "Foreign Bank Entry Experience, Implications for Developing Economies, and Agenda for Further Research." The World Bank Research Observer, 18, 25-29.

Claeys, Sophie, and Christa Hainz. (2014) "Modes of Foreign Bank Entry and Effects on Lending Rates: Theory and Evidence.” Journal of Comparative Economics, 42, 160177.

Degryse, Hans, Olena Havrylchyk, Emilia Jurzyk, and Sylwester Kozak. (2012) "Foreign Bank Entry, Credit Allocation and Lending Rates in Emerging Markets: Empirical Evidence from Poland.” Journal of Banking and Finance, 36, 2949-2959.

Degryse, Hans, Steven Ongena. (2008) "Competition and Regulation in the Banking Sector: A Review of the Empirical Evidence on the Sources of Bank Rents.” In Handbook of Financial Intermediation and Banking, pp 483-554. Elsevier.

DeYoung, Robert, Iftekhar Hasan, and Bruce Kirchhoff. (1998) "The Impact of Out-of-State Entry on the Cost Efficiency of Local Commercial Banks." Journal of Economics and Business, 50, 191-203.

De Haas, Ralph, and Iman Van Lelyveld. (2014) "Multinational Banks and the Global Financial Crisis: Weathering the Perfect Storm?" Journal of Money, Credit and Banking, 46, 333-364. 
Delis, Manthos D. (2012) "Bank Competition, Financial Reform, and Institutions: The Importance of Being Development.” Journal of Development Economics, 92, 450-465.

Delis, Manthos D, Maria Iosifidi, and Efthymios G. Tsionas. (2014) "On the Estimation of Marginal Cost.” Operations Research, 62, 543-556.

Detragiache, Enrica, Thierry Tressel, and Poonam Gupta. (2008) "Foreign Banks in Poor Countries: Theory and Evidence." Journal of Finance, 63, 2123-2160.

Evanoff, Douglas D., and Evren Ors. (2008) "The Competitive Dynamics of Geographic Deregulation in Banking: The Implications for Productive Efficiency." Journal of Money, Credit and Banking, 40, 897-928.

Giannetti, Mariassunta, and Steven Ongena. (2009) "Financial Integration and Firm Performance: Evidence from Foreign Bank Entry in Emerging Markets." Review of Finance, 13, 181-223.

Giannetti, Mariassunta, and Steven Ongena. (2012) "Lending by Example: Direct and Indirect Effects of Foreign Banks in Emerging Markets.” Journal of International Economics, 86, 167-180.

Goddard John, Phil Molyneux, and John O.S. Wilson. (2004) "Dynamics of Growth and Profitability in Banking.” Journal of Money, Credit and Banking, 36, 1069-1090.

Gormley, Todd A. (2010) "The Impact of Foreign Bank Entry in Emerging Markets: Evidence from India." Journal of Financial Intermediation, 19, 26-51.

Griffith, Rachel, Jan Boone, and Harrison, Rupert. (2005) "Measuring Competition.” AIM Research Working Paper Series 022.

Havrylchyk, Olena. (2006) "Efficiency of the Polish banking Industry: Foreign versus Domestic Banks.” Journal of Banking and Finance, 30, 1975-1996.

Havrylchyk, Olena, and Emilia Jurzyk. (2011) “Inherited or Earned? Performance of Foreign Banks in Central and Easter Europe.” Journal of Banking and Finance, 35, 1291-1302. 
Herrero, Alicia G., and Maria S. Martinez Peria. (2007) “The Mix of International Banks' Foreign Claims: Determinants and Implications." Journal of Banking and Finance, 31, 1613-1631.

Jeon, Bang N., Maria P. Olivero, and Ji Wu. (2011) "Do Foreign Banks Increase Competition? Evidence from Emerging Asian and Latin American Banking Markets." Journal of Banking and Finance, 35, 856-875.

Koetter, Michael, James W. Kolari, and Laura Spierdijk. (2012) "Enjoying the Quiet Life Under Deregulation? Evidence from Adjusted Lerner Indices for U.S. Banks.” The Review of Economics and Statistics, 94, 462-480.

La Porta, Rafael, Florencio Lopez-de-Silanes, and Andrei Shleifer. (2002) "Government Ownership of banks." Journal of Finance, 57, 265-301.

Lehner, Maria. (2009) "Entry mode Choice of Multinational banks.” Journal of Banking and Finance, 33, 1781-1792.

Lensink, Robert, and Niels Hermes. (2004) "The Short-Term effects of Foreign Bank Entry on Domestic Bank Behaviour: Does Economic Development Matter?" Journal of Banking and Finance, 28, 553-568.

Lerner, Abba P. (1934) "The Concept of Monopoly and the Measurement of Monopoly Power." The Review of Economic Studies, 1, 157-175.

Levine, Ross. (1996) "Foreign Banks, Financial Development, and Economic Growth.” In International Financial Markets, edited by Barfield Claude, pp. 224-255. Washington DC: AEI Press.

Martinez Peria, Maria S., and Ashoka Mody. (2004) "How Foreign Participation and Market Concentration Impact Bank Spreads: Evidence from Latin America." Journal of Money, Credit and Banking, 36, 511-537. 
McAllister, Patrick H., and Douglas McManus. (1993) "Resolving the Scale Efficiency Puzzle in Banking” Journal of Banking and Finance, 17, 389-405.

Mian, Atif. (2006) "Distance Constraints: The Limits of Foreign Lending in Poor Economies." Journal of Finance, 61, 1005-1056.

Micco, Alejandro, Ugo Panizza, and Monica Yanez. (2007) "Bank Ownership and Performance. Does Politics Matter?” Journal of Banking and Finance, 31, 219-241.

Moguillansky, Graciela, Rogerio Stuart, and Sebastian Vergara. (2004) "Foreign Banks in Latin America: A Paradoxical Result.” CEPAL Review, 82, 19-28.

Moulton, Brent R. (1990) “An Illustration of a Pitfall in Estimating the Effects of Aggregate Variables on Micro Unit." Review of Economics and Statistics, 72, 334-338.

Panzar, John, and James Rosse. (1987) “Testing for 'Monopoly' Equilibrium.” Journal of Industrial Economic, 35, 443-456.

Peek, Joe, Eric S. Rosengren, and Faith Kasirye. (1999) “The Poor Performance of Foreign Bank Subsidiaries: Were the Problems Acquired or Created?" Journal of Banking and Finance, 23, 579-604.

Pennathur, Anita, and Sharmila Vishwasrao. (2014) "The Financial Crisis and Bank-Client Relationships: Foreign Ownership, Transparency, and Portfolio Selection.” Journal of Banking and Finance, 42, 232-246.

Peristiani, Stavros. (1997) "Do Mergers Improve the X-Efficiency and Scale Efficiency of U.S. Banks? Evidence from the 1980s." Journal of Money, Credit and Banking, 29, 326-337.

Reiss, Peter C., and Frank A. Wolak. (2007) "Structural Econometric Modelling: Rationales and Examples from Industrial Organization.” In Handbook of Econometrics, edited by Heckman James J. and Leamer E. Edward, pp. 4277-4415. Elsevier. 
Roodman David. (2009) "How to Do Xtabond2: An Introduction to Difference and System GMM in Stata.” Stata Journal, 9, 86-136.

Schiersch, Alexander, and Lens Schmidt-Ehmcke. (2010) "Empiricism Meets Theory: Is the Boone-Indicator Applicable?” DIW Berlin, Discussion Paper 1030.

Sengupta, Rajdeep. (2007) "Foreign Entry and Bank Competition." Journal of Financial Economics, 84, 502-528.

Stiglitz, Joseph E. (1989) "Imperfect Information in the Product Market." In Handbook of Industrial Organization, edited by Schmalensee Richard and R. Willig, pp 769-847. Elsevier.

Swamy, Paravastu A.V.B. (1970) "Efficient Inference in a Random Coefficients Regression Model.” Econometrica, 38, 311-323.

Van Tessel, Eric, and Sharmila Vishwasrao. (2007) "Asymmetric Information and the Mode of Entry in Foreign Credit Markets.” Journal of Banking and Finance 31, 3742-3760.

Wheelock, David, and Paul W. Wilson. (2012) "Do Large Banks Have Lower Costs? New Estimates of Returns to Scale for US Banks.” Journal of Money, Credit, and Banking, 44, 171-99.

Windmeijer, Frank. (2005) “A Finite Sample Correction for the Variance of Linear Efficient Two-Step GMM Estimators.” Journal of Econometrics, 126, 25-51. 
Panel A: Variables used in the analysis of market power

$\begin{array}{ll}\text { Earning assets } & \begin{array}{l}\text { Natural logarithm of deflated total earning assets (measure of a bank's output). } \\ \text { Price of output }\end{array} \\ \text { Expenses } & \begin{array}{l}\text { Total income divided by total earning assets. } \\ \text { Natural logarithm of deflated total interest expenses and total noninterest expenses Bankscope } \\ \text { (measure of a bank's total cost). }\end{array} \\ \text { Price of borrowed funds } & \begin{array}{l}\text { Natural logarithm of total interest expenses divided by total customer deposits and Bankscope } \\ \text { short-term funding. }\end{array} \\ \begin{array}{l}\text { Price of labor } \\ \text { Price of physical capital } \\ \text { Price of financial capital }\end{array} & \begin{array}{l}\text { Natural logarithm of overheads minus personnel expenses divided by fixed assets. } \\ \text { Natural logarithm of equity divided by total assets }\end{array}\end{array}$

Panel B: Variables used in the analysis of market power

\section{A. Dependent variable}

Lerner index

Average Lerner index

Adj.-Lerner index

Dual-output Lerner

H-statistic

Average H-statistic

Lerner World Bank

Boone World Bank

Price-cost margin

\section{B. Bank characteristics}

Deposits

Capitalization

Loans

Bank size

\section{Main explanatory variables}

Foreign-owned

Foreign presence

Foreign presence in terms of assets

Country M\&As

Entry restrictions

Loan-loss provisions

Private ownership

Herfindahl-Hirschman index

Activity restrictions
The ability of an individual bank to charge a price above marginal cost.

The Lerner index averaged by country and year

Variant of the Lerner index which allows for the possibility that firms do not choose the prices and input levels in a profit-maximizing way.

Variant of the Lerner index that adopts a dual-output cost function.

This is the Panzar and Rosse (1987) H-statistic measured by the elasticity of bank interest revenues to input prices. The H-statistic is estimated at the bank-year level using the same technique with the Lerner indices. Higher values reflect less market power.

The H-statistic averaged by country and year

The Lerner index by country and year, where marginal cost is estimated with the usual parametric techniques and a translog cost function.

The elasticity of profits to marginal costs by country and year, where marginal cost is estimated with the usual parametric techniques and a translog cost function.

The price of output minus the marginal cost

Total customer deposits divided by total assets.

Equity capital divided by total assets.

Total loans divided by total assets.

Natural logarithm of total assets.

Dummy variable equal to one if bank is foreign owned (50\% or more of their assets)

The ratio of the number of foreign banks over the number of all banks.

The ratio of the assets of foreign banks over the total assets of all banks.

The ratio of the number of foreign-owned banks that enter via M\&As over the number of foreign-owned banks (scaled from zero to one).

The index measures the degree to which banks face entry restrictions in the banking market and is constructed by adding 1 if the answer is yes and 0 otherwise, for each one of the following twelve questions: (1) Is more than one license required (e.g. one for each banking activity)? (2) Which of the following are legally required to be submitted before issuance of the banking license: (a) draft bylaws (b) intended organizational chart (c) financial projections for first three years (d) financial information on main potential shareholders (e) background/experience of future board directors (f) background/experience of future senior managers ( $g$ ) source of funds to be used as capital. (3) What were the primary reasons for denial of the applications: (a) capital amount or quality (b) banking skills (c) reputation (d) other? This index takes a value from 0 to 12 , with larger values denoting more stringent entry restrictions.

Loan-loss provisions divided by total loans

The percentage of bank deposits held in privately owned banks were used to construct rating intervals. Countries with larger shares of privately held deposits received higher ratings.

Hirschman-Herfindahl index of each bank's total earning assets (takes value from 0 to 1).

The score for this variable is determined on the basis of the level of regulatory restrictions on bank participation in: (1) securities activities, (2) insurance activities, (3) real estate activities, and (4) bank ownership of non-financial firms. These activities can be unrestricted, permitted, restricted or prohibited and on this basis the variable is assigned the values of $1,2,3$ or 4 , respectively. The index takes a value from 0 to 16 , with larger values denoting more stringent activity restrictions.
Own calculations

Own calculations

Own calculations

Own calculations

Own calculations

Own calculations

World Bank

World Bank

Own calculation

Bankscope

Bankscope

Bankscope

Bankscope

Claessens and Van Horen (2014)

Claessens and Van Horen (2014)

Claessens and Van Horen (2014)

Claessens and Van Horen (2014)

Barth, Caprio, and Levine

(2001, 2004, 2008) and

Cihak, Demirgüç-Kunt,

Martinez Peria, and Mohseni-

Cheraghlou (2012), in the text

labeled as BCL2008

Bankscope

Economic freedom of the world 2012 Annual report

Own calculations

Barth, Caprio, and Levine (2001, 2004, 2008) and

Cihak, Demirgüç-Kunt,

Martinez Peria, and MohseniCheraghlou (2012), in the text labeled as BCL2008 
Capital requirements

Supervisory power

Manufacturing

Foreign direct investment

Government spending

Financial freedom

Trade freedom

Ideology

Polity

GDP per capita

Years of foreign

ownership $>40 \%$

Years of foreign

ownership $>50 \%$

D. Instrumental variable

Entry restriction for foreign banks
This variable is determined: (a) by adding 2, 1, or 0 if the answer is Basel II, Basel I, Barth, Caprio, and Levine or other; in the question: Which is the regulatory capital adequacy regime?, (b) by $(2001,2004,2008)$ and adding 1 if the answer is yes and 0 otherwise in the questions: Does the ratio vary Cihak, Demirgüç-Kunt, with market risk? Are the sources of funds to be used as capital verified by the regulatory/supervisory authorities?, (c) by adding 1 if the answer is no and 0 otherwise in the questions: Can the initial or subsequent injections of capital be done with assets other than cash or government securities? Can initial disbursement of capital be done with borrowed funds? This index takes a value from 0 to 6 , with larger values denoting more stringent capital requirements.

Index of the powers of the supervisor of the banking sector, reflecting whether the supervisory agency has the authority to take specific actions to prevent and correct problems in the banking sector. Takes values from 0 to 14 , with higher values reflecting more supervisory powers (see Barth, Caprio, and Levine, 2008).

The sum of gross output minus the value of intermediate inputs used in the production of manufacturing goods.

The net inflow of foreign direct investment.

The level of government expenditures as a percentage of GDP.

Index of banking security and independence from government control. Larger values indicate more freedom.

A composite measure of the absence of tariff and non-tariff barriers that affect imports and exports of goods and services. Larger values indicate more freedom.

The classification rule for the chief executive of each country is as follows: Right (1); Center (2); Left (3); No information (NA); No executive (NA).

The polity scale ranges from +10 (strongly democratic) to -10 (strongly autocratic).

Natural logarithm of GDP per capita.

The number of consecutive years since when the foreign ownership variable reached a value of $40 \%$ or higher in a specific country (zero otherwise).

The number of consecutive years since when the foreign ownership variable reached Own calculations a value of $50 \%$ or higher in a specific country (zero otherwise).

This variable is determined by adding 1 if the answer is yes and 0 otherwise, for each one of the following four questions: Are foreign entities prohibited from entering through: (1) Acquisition, (2) Subsidiary, (3) Branch and (4) Joint venture. The index takes a value from 0 to 4 , with larger values denoting more stringent entry restrictions for foreign banks.
Martinez Peria, and Mohseni-

Cheraghlou (2012), in the text

labeled as BCL2008

Barth, Caprio, and Levine

$(2001,2004,2008)$ and

Cihak, Demirgüç-Kunt,

Martinez Peria, and Mohseni-

Cheraghlou (2012), in the text

labeled as BCL2008

World Development Indicators

World Development Indicators Heritage Foundation

Heritage Foundation

Heritage Foundation

Beck, Clarke, Groff, Keefer, and Walsh (2001)

Polity IV

World Development Indicators

Own calculations

Barth, Caprio, and Levine

$(2001,2004,2008)$ and

Cihak, Demirgüç-Kunt,

Martinez Peria, and Mohseni-

Cheraghlou (2012), in the text labeled as BCL2008 
Table 2. Summary statistics

\begin{tabular}{|c|c|c|c|c|c|c|}
\hline Variable & Level & Obs. & Mean & Std. Dev. & Min. & Max. \\
\hline \multicolumn{7}{|c|}{ Panel A: Variables used in the derivation of market power from 1997-2010 } \\
\hline Earning assets & Bank & 89,514 & 11.71 & 2.02 & 6.83 & 21.38 \\
\hline Price of output & Bank & 89,514 & 0.09 & 0.07 & 0.02 & 0.71 \\
\hline Expenses & Bank & 89,514 & 8.85 & 1.93 & 4.55 & 18.41 \\
\hline Price of borrowed funds & Bank & 89,514 & -3.62 & 0.85 & -8.79 & 0.03 \\
\hline Price of labor & Bank & 89,514 & -4.30 & 0.56 & -7.18 & -2.41 \\
\hline Price of physical capital & Bank & 89,514 & -0.10 & 0.92 & -2.04 & 4.04 \\
\hline Price of financial capital & Bank & 89,514 & -2.50 & 0.59 & -8.40 & 0.00 \\
\hline Marginal cost & Bank & 89,514 & 0.07 & 0.06 & 0.01 & 1.75 \\
\hline \multicolumn{7}{|c|}{ Panel B: Variables used in the analysis of market power from 1997-2009 } \\
\hline Lerner index & Bank & 80,506 & 0.22 & 0.11 & -0.20 & 0.95 \\
\hline Lerner index with financial capital & Bank & 80,557 & 0.22 & 0.12 & -0.20 & 0.95 \\
\hline Adjusted-Lerner index & Bank & 78,634 & 0.17 & 0.12 & -0.20 & 0.95 \\
\hline Dual-output Lerner index & Bank & 74,148 & 0.21 & 0.20 & -11.54 & 0.95 \\
\hline H-statistic & Bank & 81,906 & 0.23 & 0.22 & -0.56 & 0.46 \\
\hline Lerner World Bank & Country & 81,698 & 0.21 & 0.08 & -1.61 & 0.82 \\
\hline Boone World Bank & Country & 73,920 & -0.05 & 0.10 & -2.08 & 5.69 \\
\hline Average price & Bank & 81,906 & 0.09 & 0.06 & 0.02 & 0.71 \\
\hline Marginal cost & Bank & 81,906 & 0.07 & 0.06 & 0.01 & 1.75 \\
\hline Price-cost margin & Bank & 81,906 & 0.02 & 0.02 & -1.08 & 0.41 \\
\hline Deposits & Bank & 81,906 & 0.69 & 0.20 & 0.00 & 1.00 \\
\hline Capitalization & Bank & 81,906 & 0.10 & 0.08 & 0.00 & 1.00 \\
\hline Loans & Bank & 81,839 & 0.61 & 0.19 & 0.00 & 9.36 \\
\hline Bank size & Bank & 81,906 & 12.85 & 1.66 & 7.70 & 21.51 \\
\hline Loan-loss provisions & Bank & 79,461 & 0.01 & 0.70 & -5.70 & 180.54 \\
\hline Foreign-owned & Bank & 81,906 & 0.08 & 0.27 & 0 & 1 \\
\hline Country M\&As & Country & 81,906 & 0.72 & 0.32 & 0 & 1 \\
\hline Foreign presence & Country & 81,906 & 20.60 & 16.96 & 0 & 100 \\
\hline Foreign presence in terms of assets & Country & 42,424 & 18.40 & 18.54 & 0 & 100 \\
\hline Entry restrictions & Country & 81,181 & 7.56 & 1.96 & 0 & 12 \\
\hline GDP per capita & Country & 81,864 & 10.10 & 0.82 & 6.10 & 11.21 \\
\hline Years of foreign ownership $>40 \%$ & Country & 81,906 & 0.59 & 2.13 & 0 & 13 \\
\hline Years of foreign ownership $>50 \%$ & Country & 81,906 & 0.39 & 1.70 & 0 & 13 \\
\hline Private ownership & Country & 72,596 & 7.65 & 2.46 & 0 & 10 \\
\hline Herfindahl-Hirschman index & Country & 81,906 & 0.09 & 0.14 & 0 & 1 \\
\hline Activity restrictions & Country & 81,215 & 9.01 & 2.50 & 1 & 16 \\
\hline Capital requirements & Country & 81,351 & 3.53 & 0.86 & 0 & 6 \\
\hline Supervisory power & Country & 81,301 & 11.05 & 2.27 & 1 & 14 \\
\hline Manufacturing & Country & 80,350 & 17.93 & 4.54 & 1.82 & 35.63 \\
\hline Foreign direct investment & Country & 81,735 & 5.63 & 34.26 & -15.03 & 564.92 \\
\hline Government spending & Country & 81,649 & 50.82 & 21.00 & 0 & 99.30 \\
\hline Financial freedom & Country & 81,649 & 64.18 & 18.57 & 10 & 90 \\
\hline Trade freedom & Country & 81,649 & 77.75 & 9.93 & 0 & 95 \\
\hline Ideology & Country & 77,899 & 1.64 & 1.07 & 0 & 3 \\
\hline Polity & Country & 80,325 & 8.89 & 3.17 & -10 & 10 \\
\hline Entry restrictions for foreign banks & Country & 81,744 & 0.09 & 0.33 & 0 & 4 \\
\hline
\end{tabular}

Note: The table reports summary statistics for the variables used in the empirical analysis. The variables are defined in Table 1. 
Table 3. The impact of foreign bank ownership and foreign bank presence on market power: Baseline regressions

\begin{tabular}{|c|c|c|c|c|c|c|c|c|c|c|c|}
\hline & 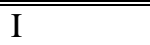 & III & IIII & $\overline{\mathrm{IV}}$ & 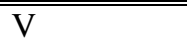 & $\overline{\mathrm{VVI}}$ & VII & VIII & IIX & $\overline{\mathrm{XX}}$ & 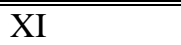 \\
\hline Dependent variable: & Lerner & Lerner & $\begin{array}{l}\text { Lerner with } \\
\text { financial } \\
\text { capital }\end{array}$ & $\begin{array}{l}\text { Lerner with } \\
\text { financial } \\
\text { capital }\end{array}$ & Adj.-Lerner & $\begin{array}{l}\text { Dual-output } \\
\text { Lerner }\end{array}$ & $\begin{array}{l}\text { Average } \\
\text { Lerner }\end{array}$ & $\begin{array}{l}\text { Lerner } \\
\text { World Bank }\end{array}$ & $\begin{array}{l}\text { Boone } \\
\text { World Bank }\end{array}$ & H-statistic & $\begin{array}{l}\text { Average H- } \\
\text { statistic }\end{array}$ \\
\hline Lagged dependent & $\begin{array}{l}0.467 * * * \\
(3.042)\end{array}$ & $\begin{array}{l}0.376^{* * *} \\
(1.989)\end{array}$ & $\begin{array}{l}0.508 * * * \\
(3.713)\end{array}$ & $\begin{array}{l}0.490 * * * \\
(3.503)\end{array}$ & $\begin{array}{l}0.607 * * * \\
(6.075)\end{array}$ & $\begin{array}{l}0.275 * * * \\
(4.038)\end{array}$ & $\begin{array}{l}0.367 * * * \\
(3.688)\end{array}$ & $\begin{array}{l}-0.361 \\
(-1.425)\end{array}$ & $\begin{array}{l}0.314 * * * \\
(4.758)\end{array}$ & $\begin{array}{l}0.362 * * * \\
(6.262)\end{array}$ & $\begin{array}{l}0.717 * * * \\
(7.464)\end{array}$ \\
\hline Deposits & $\begin{array}{l}-0.225 \\
(-1.160)\end{array}$ & $\begin{array}{l}-0.332 \\
(-1.264)\end{array}$ & $\begin{array}{l}-0.266 \\
(-1.334)\end{array}$ & $\begin{array}{l}-0.291 \\
(-1.370)\end{array}$ & $\begin{array}{l}-0.341^{*} \\
(-1.796)\end{array}$ & $\begin{array}{l}-0.182 \\
(-0.682)\end{array}$ & $\begin{array}{l}-0.408^{*} \\
(-1.862)\end{array}$ & $\begin{array}{l}-0.349 * * \\
(-2.122)\end{array}$ & $\begin{array}{l}-0.030 \\
(-0.285)\end{array}$ & $\begin{array}{l}0.259 * * \\
(2.086)\end{array}$ & $\begin{array}{l}0.028 \\
(0.269)\end{array}$ \\
\hline Capitalization & $\begin{array}{l}0.977 * * * \\
(3.900)\end{array}$ & $\begin{array}{l}1.073 * * \\
(2.438)\end{array}$ & & & $\begin{array}{l}0.907 * * * \\
(4.020)\end{array}$ & $\begin{array}{l}1.209 * * * \\
(4.405)\end{array}$ & $\begin{array}{l}0.340 * * \\
(2.232)\end{array}$ & $\begin{array}{l}0.565 \\
(0.916)\end{array}$ & $\begin{array}{l}0.048 \\
(0.387)\end{array}$ & $\begin{array}{l}0.120 \\
(0.506)\end{array}$ & $\begin{array}{l}0.129 \\
(0.819)\end{array}$ \\
\hline Loans & $\begin{array}{l}0.031 \\
(0.176)\end{array}$ & $\begin{array}{l}0.144 \\
(0.779)\end{array}$ & $\begin{array}{l}0.030 \\
(0.147)\end{array}$ & $\begin{array}{l}0.003 \\
(0.017)\end{array}$ & $\begin{array}{l}-0.032 \\
(-0.149)\end{array}$ & $\begin{array}{l}0.061 \\
(0.371)\end{array}$ & $\begin{array}{l}-0.155 \\
(-1.283)\end{array}$ & $\begin{array}{l}0.068 \\
(0.151)\end{array}$ & $\begin{array}{l}-0.210^{*} \\
(-1.683)\end{array}$ & $\begin{array}{l}-0.184 \\
(-1.367)\end{array}$ & $\begin{array}{l}-0.107 \\
(-1.088)\end{array}$ \\
\hline Bank size & $\begin{array}{l}0.043 \\
(1.488)\end{array}$ & $\begin{array}{l}0.067 \\
(0.811)\end{array}$ & $\begin{array}{l}0.018 \\
(0.461)\end{array}$ & $\begin{array}{l}0.015 \\
(0.412)\end{array}$ & $\begin{array}{l}0.017 \\
(0.641)\end{array}$ & $\begin{array}{l}0.067 * * \\
(2.420)\end{array}$ & $\begin{array}{l}0.031 \\
(1.183)\end{array}$ & $\begin{array}{l}0.008 \\
(0.113)\end{array}$ & $\begin{array}{l}-0.050 * * \\
(-2.106)\end{array}$ & $\begin{array}{l}-0.058 \\
(-1.069)\end{array}$ & $\begin{array}{l}-0.022 \\
(-0.552)\end{array}$ \\
\hline Foreign-owned & $\begin{array}{l}-0.230 \\
(-1.005)\end{array}$ & $\begin{array}{l}0.049 \\
(0.193)\end{array}$ & $\begin{array}{l}-0.251 \\
(-1.031)\end{array}$ & $\begin{array}{l}-0.249 \\
(-0.977)\end{array}$ & $\begin{array}{l}-0.208 \\
(-1.019)\end{array}$ & $\begin{array}{l}0.099 \\
(0.640)\end{array}$ & $\begin{array}{l}0.074 \\
(0.498)\end{array}$ & $\begin{array}{l}-0.107 \\
(-0.288)\end{array}$ & $\begin{array}{l}-0.131 \\
(-0.474)\end{array}$ & $\begin{array}{l}0.755^{*} \\
(1.771)\end{array}$ & $\begin{array}{l}0.267 \\
(1.244)\end{array}$ \\
\hline Foreign presence & $\begin{array}{l}0.009 * * \\
(2.506)\end{array}$ & & $\begin{array}{l}0.010 * * \\
(2.431)\end{array}$ & $\begin{array}{l}0.010 * * \\
(2.482)\end{array}$ & $\begin{array}{l}0.007 * * \\
(2.138)\end{array}$ & $\begin{array}{l}0.005 * * \\
(2.267)\end{array}$ & $\begin{array}{l}0.010 * * * \\
(3.088)\end{array}$ & $\begin{array}{l}0.016 * * * \\
(3.629)\end{array}$ & $\begin{array}{l}0.004^{*} \\
(1.954)\end{array}$ & $\begin{array}{l}0.001 \\
(0.210)\end{array}$ & $\begin{array}{l}0.001 \\
(0.526)\end{array}$ \\
\hline $\begin{array}{l}\text { Foreign presence in } \\
\text { terms of assets }\end{array}$ & & $\begin{array}{l}0.003 * * * \\
(2.617)\end{array}$ & & & & & & & & & \\
\hline Entry restrictions & $\begin{array}{l}0.014 * * * \\
(5.956)\end{array}$ & $\begin{array}{l}0.045 \\
(1.513)\end{array}$ & $\begin{array}{l}0.015 * * * \\
(6.182)\end{array}$ & $\begin{array}{l}0.015 * * * \\
(5.856)\end{array}$ & $\begin{array}{l}0.012 * * * \\
(4.018)\end{array}$ & $\begin{array}{l}0.007 * * \\
(2.286)\end{array}$ & $\begin{array}{l}0.009 * * * \\
(3.031)\end{array}$ & $\begin{array}{l}0.026 * * \\
(2.569)\end{array}$ & $\begin{array}{l}-0.001 \\
(-0.193)\end{array}$ & $\begin{array}{l}-0.003 \\
(-0.718)\end{array}$ & $\begin{array}{l}-0.002 \\
(-0.948)\end{array}$ \\
\hline GDP per capita & $\begin{array}{l}-0.297 * * \\
(-2.149)\end{array}$ & $\begin{array}{l}-0.255 \\
(-0.546)\end{array}$ & $\begin{array}{l}-0.322^{*} \\
(-1.747)\end{array}$ & $\begin{array}{l}-0.282 \\
(-1.575)\end{array}$ & $\begin{array}{l}-0.146 \\
(-0.997)\end{array}$ & $\begin{array}{l}-0.045 \\
(-0.272) \\
\end{array}$ & $\begin{array}{l}-0.097 \\
(-0.680)\end{array}$ & $\begin{array}{l}-0.044 \\
(-0.164)\end{array}$ & $\begin{array}{l}0.256 \\
(1.196)\end{array}$ & $\begin{array}{l}-0.011 \\
(-0.037)\end{array}$ & $\begin{array}{l}0.138 \\
(0.613)\end{array}$ \\
\hline Observations & 49,776 & 25,837 & 49,830 & 49,769 & 47,125 & 55,855 & 51,216 & 61,653 & 55,613 & 51,173 & 51,217 \\
\hline Wald & 0.000 & 0.000 & 0.000 & 0.000 & 0.000 & 0.000 & 0.000 & 0.000 & 0.000 & 0.000 & 0.000 \\
\hline Hansen (overall) & 0.329 & 0.143 & 0.297 & 0.289 & 0.284 & 0.516 & 0.423 & 0.447 & 0.637 & 0.809 & 0.749 \\
\hline Hansen (IV style) & 0.229 & 0.440 & 0.120 & 0.264 & 0.616 & 0.452 & 0.426 & 0.136 & 0.595 & 0.762 & 0.306 \\
\hline AR1 & 0.003 & 0.035 & 0.001 & 0.001 & 0.000 & 0.000 & 0.006 & 0.357 & 0.000 & 0.000 & 0.000 \\
\hline AR2 & 0.988 & 0.599 & 0.912 & 0.994 & 0.538 & 0.324 & 0.107 & 0.924 & 0.247 & 0.202 & 0.815 \\
\hline
\end{tabular}

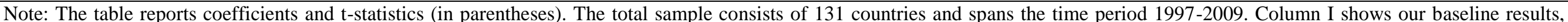

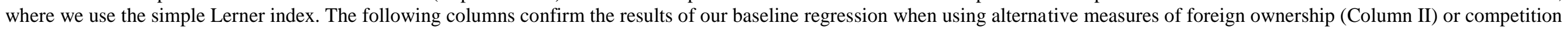

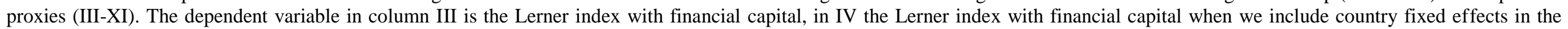

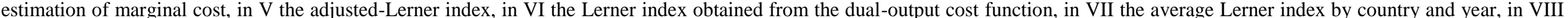

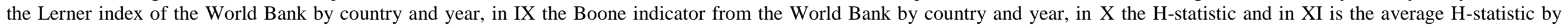

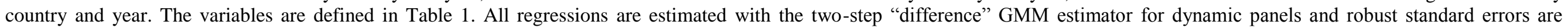

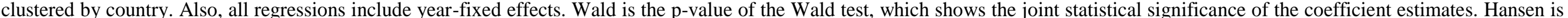

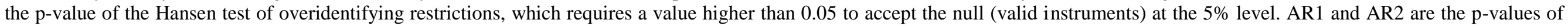

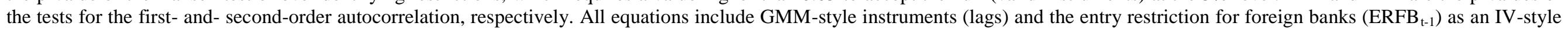
instrument. The $* * *, * * *$ marks denote statistical significance at the 10,5 , and $1 \%$ level, respectively. 
Table 4. Foreign bank presence and market power: Evolution of the effect over time

\begin{tabular}{|c|c|c|c|c|c|c|}
\hline \multirow[b]{2}{*}{$\begin{array}{l}\text { Heterogeneous } \\
\text { effect due to: }\end{array}$} & $\overline{\mathrm{II}}$ & 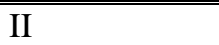 & 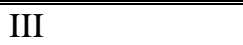 & IIV & 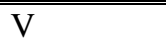 & "VI \\
\hline & $\begin{array}{l}\text { Years of } \\
\text { foreign } \\
\text { ownership }>40 \\
\%\end{array}$ & $\begin{array}{l}\text { Years of } \\
\text { foreign } \\
\text { ownership }>50 \\
\%\end{array}$ & $\begin{array}{l}\text { Evolution of the } \\
\text { effect of foreign } \\
\text { presence }\end{array}$ & $\begin{array}{l}\text { Evolution of the } \\
\text { effect of foreign- } \\
\text { owned }\end{array}$ & $\begin{array}{l}\text { Treatment } \\
\text { effect( } 1 \\
\text { year) }\end{array}$ & $\begin{array}{l}\text { Treatment } \\
\text { effect( } 2 \\
\text { year) }\end{array}$ \\
\hline \multirow[t]{2}{*}{ Lagged dependent } & $0.470 * * *$ & $0.456 * * *$ & $0.452 * * *$ & $0.468 * * *$ & & \\
\hline & $(3.760)$ & $(3.070)$ & $(4.153)$ & $(3.686)$ & & \\
\hline \multirow[t]{2}{*}{ Deposits } & -0.231 & $-0.256^{*}$ & -0.109 & -0.119 & $0.034 * * *$ & $0.065 * * *$ \\
\hline & $(-1.450)$ & $(-1.766)$ & $(-0.647)$ & $(-0.586)$ & $(6.377)$ & $(8.800)$ \\
\hline \multirow[t]{2}{*}{ Capitalization } & $0.803 * * *$ & $0.800 * * *$ & $1.019 * * *$ & $1.098 * * *$ & $-0.078 * * *$ & $-0.112 * * *$ \\
\hline & $(3.368)$ & $(3.523)$ & $(4.355)$ & $(4.626)$ & $(-6.250)$ & $(-6.485)$ \\
\hline \multirow[t]{2}{*}{ Loans } & 0.078 & 0.041 & $0.220^{*}$ & 0.188 & $0.028 * * *$ & $0.034 * * *$ \\
\hline & $(0.588)$ & $(0.290)$ & $(1.660)$ & $(1.310)$ & $(6.665)$ & $(6.129)$ \\
\hline \multirow[t]{2}{*}{ Bank size } & $0.057 * * *$ & $0.046 * *$ & 0.049 & 0.044 & $0.008 * * *$ & $0.006 * * *$ \\
\hline & $(2.598)$ & $(2.116)$ & $(1.244)$ & $(0.922)$ & $(4.778)$ & $(2.672)$ \\
\hline \multirow[t]{2}{*}{ Foreign-owned } & -0.270 & -0.234 & $-0.435^{*}$ & -0.389 & 0.070 & 0.180 \\
\hline & $(-1.372)$ & $(-1.143)$ & $(-1.877)$ & $(-1.452)$ & $(0.50)$ & $(1.20)$ \\
\hline \multirow[t]{2}{*}{ Foreign-owned (t-3) } & & & & -0.060 & & \\
\hline & & & & $(-0.247)$ & & \\
\hline \multirow[t]{2}{*}{ Foreign presence } & $0.005 * *$ & $0.007 * * *$ & $0.010 * * *$ & $0.011 * *$ & $0.001 * * *$ & 0.000 \\
\hline & $(2.255)$ & $(2.726)$ & $(2.599)$ & $(2.316)$ & $(4.434)$ & $(0.854)$ \\
\hline \multirow[t]{2}{*}{ Foreign presence $(\mathrm{t}-3)$} & & & -0.003 & & & \\
\hline & & & $(-1.105)$ & & & \\
\hline \multirow[t]{2}{*}{ Entry restrictions } & $0.013 * * *$ & $0.014 * * *$ & $0.015^{* * *}$ & $0.016 * * *$ & $0.003 * * *$ & $0.010 * * *$ \\
\hline & $(6.957)$ & $(7.513)$ & $(5.042)$ & $(5.222)$ & $(7.805)$ & $(18.918)$ \\
\hline \multirow[t]{2}{*}{ GDP per capita } & $-0.290 *$ & -0.261 & $-0.418 * * *$ & $-0.440 * * *$ & $-0.083 * * *$ & $-0.238 * * *$ \\
\hline & $(-1.754)$ & $(-1.549)$ & $(-3.020)$ & $(-2.865)$ & $(-6.145)$ & $(-12.464)$ \\
\hline \multirow{2}{*}{$\begin{array}{l}\text { Years of foreign } \\
\text { ownership }\end{array}$} & $-0.036^{*}$ & -0.040 & & & & \\
\hline & $(-1.669)$ & $(-1.521)$ & & & & \\
\hline Foreign presence $*$ & $0.001 *$ & $0.001 *$ & & & & \\
\hline $\begin{array}{l}\text { Years of foreign } \\
\text { ownership }\end{array}$ & (1.855) & (1.736) & & & & \\
\hline Observations & 49,733 & 49,733 & 41,037 & 41,037 & 60,728 & 51,107 \\
\hline Wald & 0.000 & 0.000 & 0.000 & 0.000 & 0.000 & 0.000 \\
\hline Hansen (overall) & 0.859 & 0.977 & 0.260 & 0.158 & & \\
\hline Hansen (IV style) & 0.834 & 0.946 & 0.282 & 0.151 & & \\
\hline AR1 & 0.001 & 0.003 & 0.000 & 0.001 & & \\
\hline AR2 & 0.948 & 0.913 & 0.272 & 0.659 & & \\
\hline
\end{tabular}

Note: This table reports coefficients and t-statistics (in parentheses). The dependent variable is the Lerner index. The variables are defined in Table 1. Columns I-IV are estimated with the two-step "difference" GMM for dynamic panels and robust standard errors clustered by country. Columns V-VI are estimated with treatment effects model. Also, all regressions include year-fixed effects. Wald is the p-value of the Wald test, which shows the joint statistical significance of the coefficient estimates. Hansen is the p-value of the Hansen test of overidentifying restrictions, which requires a value higher than 0.05 to accept the null (valid instruments) at the 5\% level. AR1 and AR2 are the p-values of the tests for the first- and- second-order autocorrelation, respectively. All equations include the entry restriction for foreign banks $\left.\left(E_{R F B}\right)_{t-1}\right)$ as an IV-style instrument. Columns I-IV include GMM-style instruments (lags). The *, **, *** marks denote statistical significance at the 10, 5, and 1\% level, respectively. 
Table 5. Foreign bank presence and subcomponents of the Lerner index

\begin{tabular}{llll}
\hline \hline & I & II & III \\
\cline { 2 - 4 } Dependent variable: & Price & Marginal Cost & Price-cost margin \\
\hline Lagged dependent & $0.495^{* * *}$ & $0.743^{* * *}$ & $0.464^{* * *}$ \\
Deposits & $(4.37)$ & $(5.170)$ & $(7.791)$ \\
& 0.175 & -0.013 & $-0.082^{* *}$ \\
Capitalization & $(1.330)$ & $(-0.24)$ & $(-2.137)$ \\
& $0.341^{*}$ & -0.060 & $0.241^{* * *}$ \\
Loans & $(0.206)$ & $(-0.540)$ & $(5.603)$ \\
& -0.141 & -0.151 & -0.038 \\
Bank size & $(-1.680)$ & $(-1.620)$ & $(-1.268)$ \\
& -0.054 & -0.022 & 0.002 \\
Foreign-owned & $(-1.510)$ & $(-1.050)$ & $(0.434)$ \\
Foreign presence & 0.200 & 0.153 & 0.024 \\
Entry restrictions & $(0.990)$ & $(1.140)$ & $(0.794)$ \\
& 0.001 & $-0.002^{*}$ & $0.002^{* *}$ \\
GDP per capita & $(0.780)$ & $(-1.730)$ & $(2.476)$ \\
& $-0.007 *$ & 0.007 & $-0.014 * * *$ \\
\hline Observations & $(-1.777)$ & $(-1.440)$ & $(-3.273)$ \\
Wald & 0.372 & $0.426 *$ & -0.011 \\
Hansen (overall) & $(1.260)$ & $(1.65)$ & $(-0.444)$ \\
Hansen (IV style) & 51,173 & 61,740 & 51,173 \\
AR1 & 0.000 & 0.000 & 0.000 \\
AR2 & 0.306 & 0.456 & 0.665 \\
\hline \hline
\end{tabular}

Note: The table reports coefficients and t-statistics (in parentheses). The dependent variable in column I is the average price of bank activities (P), in II the marginal cost (MC), and in III the price-cost margin (the difference between price and marginal cost). The variables are defined in Table 1. All regressions are estimated with the two-step "difference" GMM for dynamic panels and robust standard errors clustered by country. Also, all regressions include year-fixed effects. Wald is the p-value of the Wald test, which shows the joint statistical significance of the coefficient estimates. Hansen is the p-value of the Hansen test of overidentifying restrictions, which requires a value higher than 0.05 to accept the null (valid instruments) at the 5\% level. AR1 and AR2 are the p-values of the tests for the first- and- secondorder autocorrelation, respectively. All equations include GMM-style instruments (lags) and the entry restriction for foreign banks (ERFBt-1) as an IV-style instrument. The *, **, *** marks denote statistical significance at the 10,5 , and $1 \%$ level, respectively. 
Table 6. Foreign bank presence and market power: The mode of foreign bank entry

\begin{tabular}{|c|c|c|c|c|c|c|}
\hline & $\mathrm{I}$ & II & III & IV & $\mathrm{V}$ & VI \\
\hline Dependent variable: & Lerner & Lerner & $\begin{array}{l}\text { Average } \\
\text { Lerner }\end{array}$ & Price & $\begin{array}{l}\text { Marginal } \\
\text { cost }\end{array}$ & $\begin{array}{l}\text { Price-cost } \\
\text { Margin }\end{array}$ \\
\hline Lagged dependent & $\begin{array}{l}0.450 \text { *** } \\
(3.489)\end{array}$ & $\begin{array}{l}0.447 * * * \\
(3.283)\end{array}$ & $\begin{array}{l}0.399 * * * \\
(3.271)\end{array}$ & $\begin{array}{l}0.636 * * * \\
(5.930)\end{array}$ & $\begin{array}{l}0.663 * * * \\
(4.430)\end{array}$ & $\begin{array}{l}0.474 * * * \\
(8.469)\end{array}$ \\
\hline Foreign-owned & $\begin{array}{l}-0.326 \\
(-1.166)\end{array}$ & $\begin{array}{l}-0.046 \\
(-1.201)\end{array}$ & $\begin{array}{l}0.016 \\
(0.087)\end{array}$ & $\begin{array}{l}0.218 \\
(0.960)\end{array}$ & $\begin{array}{l}0.080 \\
(0.790)\end{array}$ & $\begin{array}{l}0.010 \\
(0.313)\end{array}$ \\
\hline Foreign presence & $\begin{array}{l}0.008 * * \\
(2.196)\end{array}$ & $\begin{array}{l}0.005 \\
(1.267)\end{array}$ & $\begin{array}{l}0.008 * * \\
(2.305)\end{array}$ & $\begin{array}{l}0.001 \\
(-0.350)\end{array}$ & $\begin{array}{l}-0.002 \\
(-1.010)\end{array}$ & $\begin{array}{l}0.001 \\
(1.217)\end{array}$ \\
\hline Country M\&As & $\begin{array}{l}0.057 \\
(0.891)\end{array}$ & $\begin{array}{l}0.061 \\
(0.912)\end{array}$ & $\begin{array}{l}0.049 \\
(0.865)\end{array}$ & $\begin{array}{l}0.073 \\
(0.930)\end{array}$ & $\begin{array}{l}-0.004 \\
(-0.200)\end{array}$ & $\begin{array}{l}0.008 \\
(1.111)\end{array}$ \\
\hline $\begin{array}{l}\text { Foreign presence } * \text { Country } \\
\text { M\&As }\end{array}$ & $\begin{array}{l}0.010 * * \\
(2.101)\end{array}$ & $\begin{array}{l}0.011 * * \\
(2.145)\end{array}$ & $\begin{array}{l}0.010^{*} \\
(1.909)\end{array}$ & $\begin{array}{l}0.003 \\
(0.870)\end{array}$ & $\begin{array}{l}-0.001^{*} \\
(-1.750)\end{array}$ & $\begin{array}{l}0.001 * * \\
(2.555)\end{array}$ \\
\hline Observations & 49,776 & 46,842 & 51,216 & 51,173 & 61,740 & 51,173 \\
\hline Wald & 0.000 & 0.000 & 0.000 & 0.000 & 0.000 & 0.000 \\
\hline Hansen (overall) & 0.134 & 0.276 & 0.497 & 0.447 & 0.364 & 0.471 \\
\hline Hansen (IV style) & 0.468 & 0.296 & 0.300 & 0.416 & 0.428 & 0.265 \\
\hline AR1 & 0.001 & 0.002 & 0.000 & 0.000 & 0.000 & 0.000 \\
\hline AR2 & 0.607 & 0.528 & 0.726 & 0.971 & 0.630 & 0.212 \\
\hline Bank characteristics & Yes & Yes & Yes & Yes & Yes & Yes \\
\hline Country characteristics & Yes & Yes & Yes & Yes & Yes & Yes \\
\hline
\end{tabular}

Note: The table reports coefficients and t-statistics (in parentheses). The dependent variable in columns I-II is the Lerner index, in III the average Lerner index, in III the average price of bank activities (P), in IV the marginal cost (MC), and in V the price-cost margin (the difference between price and marginal cost). The variables are defined in Table 1. All regressions are estimated with the two-step "difference" GMM for dynamic panels and robust standard errors clustered by country. Also, all regressions include year-fixed effects and the control variables included in Table 3. Wald is the p-value of the Wald test, which shows the joint statistical significance of the coefficient estimates. Hansen is the p-value of the Hansen test of overidentifying restrictions, which requires a value higher than 0.05 to accept the null (valid instruments) at the 5\% level. AR1 and AR2 are the p-values of the tests for the first- and- second-order autocorrelation, respectively. All equations include GMM-style instruments (lags) and the entry restriction for foreign banks (ERFBt-1) as an IV-style instrument. The *,**,*** marks denote statistical significance at the 10, 5, and $1 \%$ level, respectively. 
Table 7. Foreign bank presence and market power: The effect of the crisis

\begin{tabular}{|c|c|c|c|c|}
\hline & I & II & IIII & IV \\
\hline Threshold: & Pre-crisis & $\begin{array}{l}\text { Pre-crisis } \\
\text { type of entry }\end{array}$ & Post-crisis & $\begin{array}{l}\text { Post-crisis } \\
\text { type of entry }\end{array}$ \\
\hline Lagged dependent & $\begin{array}{l}0.451 * * * \\
(4.927)\end{array}$ & $\begin{array}{l}0.391 * * \\
(2.523)\end{array}$ & $\begin{array}{l}0.413 \\
-1.322\end{array}$ & $\begin{array}{l}0.388 * * * \\
(5.265)\end{array}$ \\
\hline Foreign-owned & $\begin{array}{l}0.283 \\
(0.881)\end{array}$ & $\begin{array}{l}0.087 \\
(0.290)\end{array}$ & $\begin{array}{l}-0.260 \\
(-0.880)\end{array}$ & $\begin{array}{l}-0.115 \\
(-0.407)\end{array}$ \\
\hline Foreign presence & $\begin{array}{l}0.010 * * \\
(2.190)\end{array}$ & $\begin{array}{l}0.011 * * \\
(1.967)\end{array}$ & $\begin{array}{l}0.011 * * \\
-1.998\end{array}$ & $\begin{array}{l}0.009 * * \\
(2.103)\end{array}$ \\
\hline Country M\&As & & $\begin{array}{l}0.024 \\
(0.568)\end{array}$ & & $\begin{array}{l}0.140^{*} \\
(1.924)\end{array}$ \\
\hline Foreign presence $*$ Country M\&As & & $\begin{array}{l}0.009 * * \\
(2.074)\end{array}$ & & $\begin{array}{l}0.014 * * \\
(2.250)\end{array}$ \\
\hline Observations & 27,916 & 27,916 & 21,860 & 24,641 \\
\hline Wald & 0.000 & 0.000 & 0.000 & 0.000 \\
\hline Hansen (overall) & 0.779 & 0.706 & 0.544 & 0.878 \\
\hline Hansen (IV style) & 0.695 & 0.560 & 0.669 & 0.558 \\
\hline AR1 & 0.000 & 0.012 & 0.143 & 0.000 \\
\hline AR2 & 0.331 & 0.222 & 0.919 & 0.061 \\
\hline Bank characteristics & Yes & Yes & Yes & Yes \\
\hline Country characteristics & Yes & Yes & Yes & Yes \\
\hline
\end{tabular}

Note: The table reports coefficients and t-statistics (in parentheses). The dependent variable is the Lerner index. In columns I-II we limit our sample to the pre-2007 period and in columns III-IV to the post-2007 period. The variables are defined in Table 1. All regressions are estimated with the two-step "difference" GMM for dynamic panels and robust standard errors clustered by country. Also, all regressions include yearfixed effects and the control variables included in Table 3. Wald is the p-value of the Wald test, which shows the joint statistical significance of the coefficient estimates. Hansen is the p-value of the Hansen test of overidentifying restrictions, which requires a value higher than 0.05 to accept the null (valid instruments) at the 5\% level. AR1 and AR2 are the p-values of the tests for the first- and- second-order autocorrelation, respectively. All equations include GMM-style instruments (lags) and the entry restriction for foreign banks $\left(\mathrm{ERFB}_{\mathrm{t}-1}\right)$ as an IV-style instrument. The *, **, *** marks denote statistical significance at the 10, 5, and 1\% level, respectively. 


\section{Figure 1}

Evolution of the average Lerner indices by year

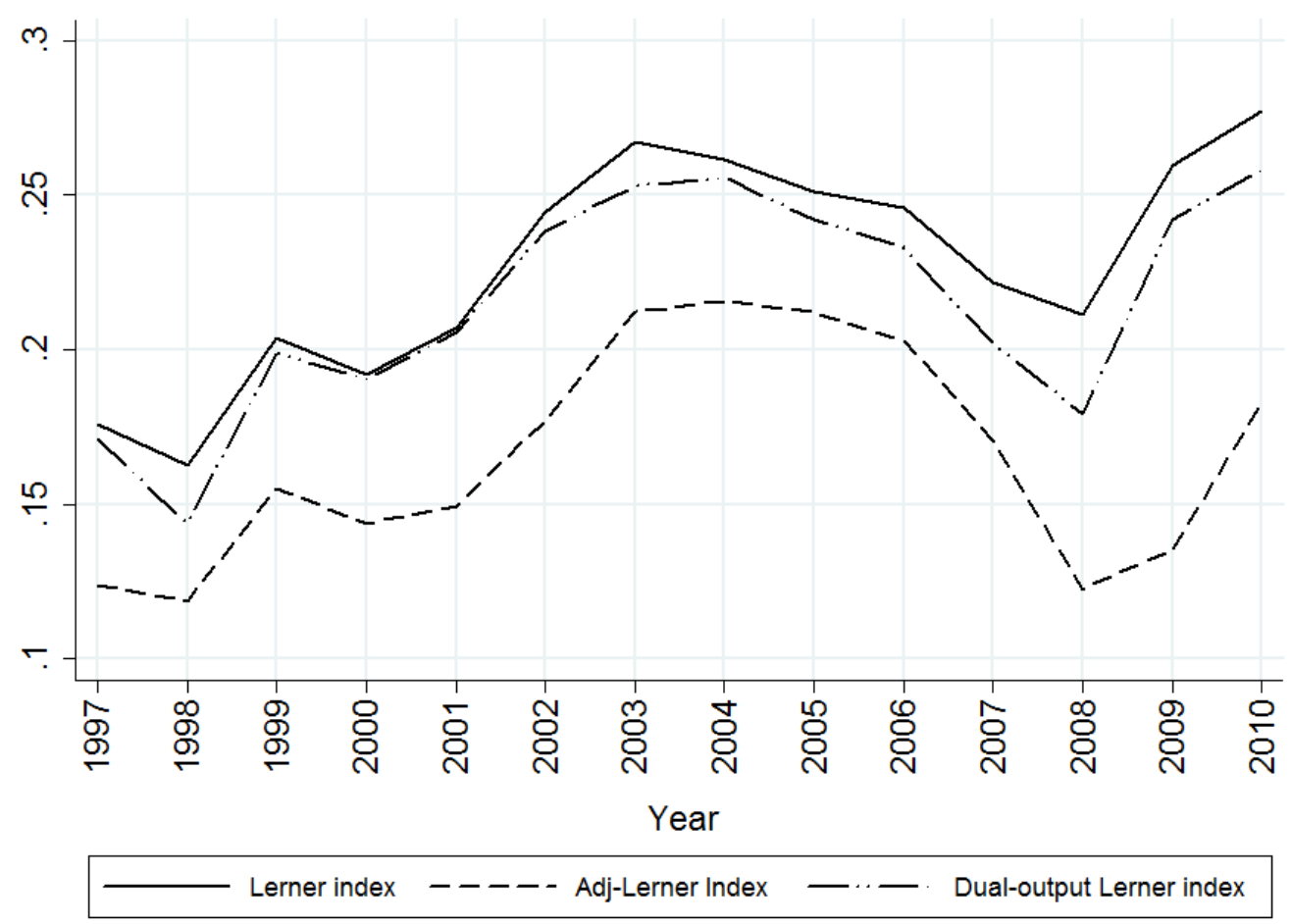


Figure 2

Foreign bank presence and banks' market power

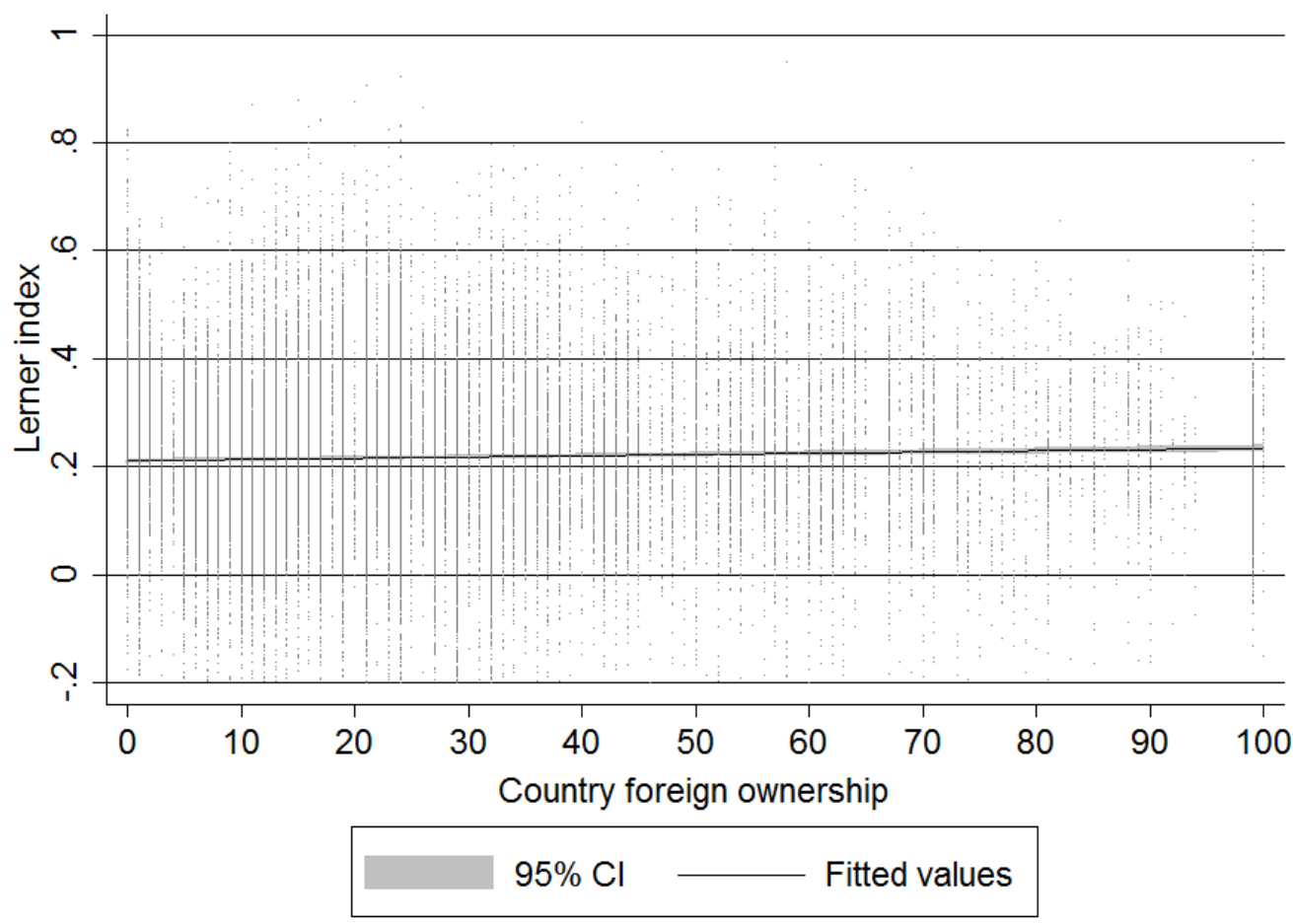

